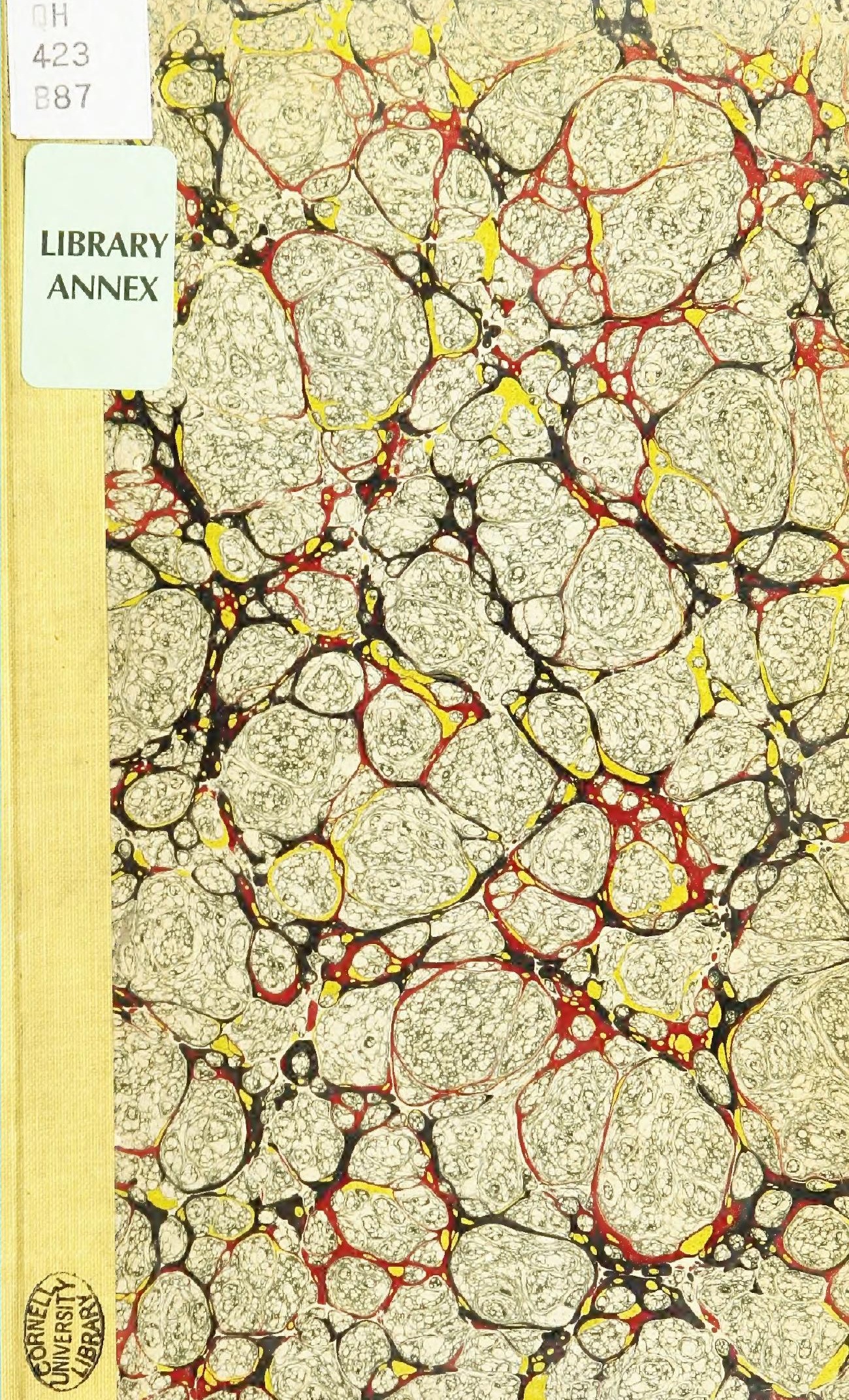




\section{Cornell University Library}

The original of this book is in the Cornell University Library.

There are no known copyright restrictions in the United States on the use of the text. 


\section{OH 423.B87}

\section{Form and structure of certain plant hybr}

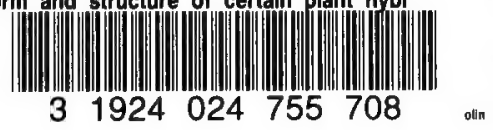





\title{
Form and Structure of Certain Plant Hybrids in Comparison with the Form and Structure of their Parents
}

\author{
A THESIS \\ Presented TO THE FACULTy OF THE GRaduate School \\ OF CORNELL UNIVERSITY FOR THE DEGREE OF \\ DOCTOR OF PHILOSOPHY
}

BY

HARRY BATES $\underset{=}{\text { BROWN }}$

Reprinted from Technical Bulletin No. 3, Miss. Agr. Exp. Sta. Jan. I9I3. 



\title{
Form and Structure of Certain Plant Hybrids in Comparison With the Form and Structure of their Parents.
}

\author{
By HARRY B. BROWN.
}

\section{INTRODUCTION.}

Notwithstanding the fact that plant hybrids have claimed much attention for many years and have been considered as creations of special interest by gardeners, horticulturalists, and scientists in general, with few exceptions, only their external or morphological characters have been studied. The histological characters, although numerous, well defined, and fundamental to the plant in its organization, have been largely overlooked, and their inheritance not considered. In this investigation, special attention has been paid to the microscopical structure of the hybrids studied and to inheritance of histological characters. An effort was also made to determine whether or not there is a definite relation existing between external and internal characters, or a correlation in the inheritance of the two sets of characters.

In taking up this study, the first task was to produce hybrids between parents as widely separated in histological and morphological characters as possible. To this end the greater part of the summer of 1908 was spent trying to make crosses between widely distinct plants. Crosses were attempted between plants belonging to different species, genera and even families. As a result, hybrids were obtained between three very distinct species of Nicotiana,-Nicotiana Tabacum $\mathrm{x} N$. sylvestris, and N. Tabacum x N. alata, and also a hybrid between plants belonging to the two genera Raphanus and Brassica, Raphanus sativus (Radish) x Brassica oleracea var. caulo-rapa (Kohlrabi). These first generation hybrids, together with plants from self fertilized seed of the parent plants were grown during the summer of 1909. During this summer photographs were made, notes and measurements taken, and material fixed and preserved for histological study. Chrom-acetic acid fixer made up after the formula in common use, and Gilson's fixer were used. Most of the material was imbedded in celloidin for sectioning, but paraffin was used in all cases wherever possible.

In addition to the hybrids mentioned above, the structure of certain others, was studied in some detail. I am indebted to Dr. H. J. Webber for the fruit of Citrus trifoliata and the fruit of seven different hybrids between Citrus trifoliata and Citrus aurantium; to Mr. J. B. Frost for leaves of a hybrid strawberry plant and also leaves of the parent plants; Mr. J. W. Kerr of Denton, Md., for living twigs of a hybrid between Wild Goose Plum and Troth's Early Peach; to Mr. M. J. Dorsey of 
the New York Experimental Station, Geneva, N. Y., for living twigs of Wild Goose Plum and Troth's Early Peach; to Prof. B. D. Halstead for seed of certain varieties of corn and tomatoes, and the seed of hybrids; and to Prof. W. W. Rowlee for specimens of Salix cordata, Salix candida and a hybrid between the two.

After a description of the external features of each hybrid, the microscopical istructure of parents and hybrids is given in detail. Following this is a more general discussion covering the conclusions to be drawn from the study and their relation to certain questions of biological importiance.

The more striking features of hybrids and parents, both macroscopical and microscopical are illustrated by the accompanying photographs, and photomicrographs.

Precautions were taken to secure corresponding parts of the different plants. Parts that varied considerably on account of age, or for other reasons, were not used. The seed was all planted on the same day, plants transplanted the same day, and in so far as possible, the same conditions of soil, cultivation, etc., were provided.

\section{Historical Review.}

It is said that Linnaeus recognized certain plant hybrids in the wild state and afterwards produced them artificially. From his time to the present, many scientists and particularly, horticulturists and gardeners have produced and studied hybrid plants. Most of the study, however, has been devoted to the external form of the hybrid,habit, shape of leaves, flowers, relative fertility, etc. But a comparatively small amount of attention has been given to the study of their microscopical characters.

Henslow, in 1831, compared a hybrid Digitalis with its parents with a degree of minuteness remarkable for his time. He thought that the morphological characters of the hybrid were exactly intermediate between those of its parents, but that the histological characters were the same in the three plants. Wichura (1865) showed that willow hybrids are intermediate in structure, and Kerner (1878) showed the same to be true of hybrid Pulmonarias. Wettstein (1888) compared the structure of the leaves of four coniferous hybrids with that of their parents, noting especially the general arrangement of tissues. $\mathrm{He}$ found that the characters of the hybrid leaves were in most respects, exactly intermediate between those of the parents. MacFarlane (1890, 1891,1900 ) has probably devoted more time to the study of the minute structure of hybrids than any other student. In 1890 he described the structure of seventeen hybrid Sarracenias, together with others included in his monograph published later. From this study, he was inclined to believe that a hybrid plant contained a blending of parental peculiarities in every cell. These were especially demonstrated in epidermal cells. In 1891 his extensive monograph appeared (MacFarlane 91-a); in this work he described the structural details of the following hybrids: Philageria Veitchii, Dianthus Grievei, Geum intermedium, Ribes Culverwelli, Saxifraga Andrewsii, Erica Watsoni, Bryanthus erectus, Masdevallia Chelsoni, and Cypripedium Leeanum. 
The structure of the parents was also described and the hybrids compared with them.

The main conclusion reached from a study of these hybrids and a number of others not named, was that the structure of hybrids is almost exactly intermediate between that of the parents.

Wunderlich (1895) studied the structure of more than twenty hybrids betwcen different species of Cirsium. He found that in the main the hybrids were intermediate between their parents anatomically; the hybrids showing in several cases an exact arithmetical mean between the parents in the number of layers of cells in particular parts. The hrbrid betwecn Cirsium bulbosum and $\mathrm{C}$. acaule showed for the most part the anatcmical characters of $\mathrm{C}$. bulbosum showing a dominance in anatomical characters. In instances in which the two farents possessed different corresponding characters, as in the case of two sorts of hairs, the hybrid produced both forms.

Zschokkc (1895) found that the anatomy of a hybrid between Carex ampullacea and C. vesicaria was intermediate between that of its parents.

Parmentier (1897) described the structure of a number of Rosa hybrids. They were intermediate in the main, but different ones showed a leaning to one of the parents in certain characters. No very striking conclusions were reached.

Farmer (1897) reported that the hybrid fern Polypodium Schneideri, showed certain structural characters somewhat intermediate between those of its parents, yet in the main, the characters were almost exactly like characters found in one or the other of the two parents, blending not being apparint.

Paulesco (1900) compared the structure of hybrids and parent plants in the genera Achillea, Senecio, Cirsium, Rosa, Dentaria, Sorbus, Tilia, Viola, Primula, Rhododendron, Cistus, and Salix. He found that the hybrids either resembled one parent closely or were intermediate. In some cases certain organs resembled those of one parent, while other parts were intermediate. Epidermal hairs were found to be intermediate in some cases, in others larger and more numerous than in either parent; if the parents possessed two different sorts of hairs the hybrid usually had both.

Wilson (1900) discussed hybrids in the genera Passiflora, Ribes and Begonia. This work dealt mainly with the external appearance of the hybrids, Passiflora Buonapartea x P. caerulea, P. alba x P. Buonapartea, Ribes nigrum $x$ R. grossularia, and Tuberous Begonia x B. coccinea. These hybrids were said to be intermediate in characters examined.

MacFarlane (1900) described the structure of a hybrid Drosera, D. filiformis $\times$ D. intermedia. The structure of the hybrid showed a minute blending of parental histological peculiarities in all parts; leaves, axis of inflorescence, inflorescence, period of blooming, size and color of blossoms, and floral structure, were all intermediate. Briquet (1901) reported a combination of the histological characters of the parents in Laportea hybrids.

Gauchery (1902) in comparing the tissues of Garrya ellipticoFadhenii with that of its parents G. elliptica and G. Fadyenii, found 
that the hybrid inherited from G. elliptica (its pollen parent), its epidermis, epidermal structures, and its mesophyll, while strengthening tissue was inherited from the other parent. Other parts were intermediate. Cistus Salvifolius x Helianthemum halimifolium showed much the same when compared with its parents. From these cases the author was of the opinion that the pollen parent could be determined by a study of the epidermis of the hybrid.

Daguillon (1905), from a study of the structure of Linaria ochroleuca in comparison with L. striata and L. vulgaris, confirmed the supposition that the former was a hybrid between the other two species. The structural characters were mostly of an intermediate nature.

Penhallow (1905) studied the structure of a hybrid Catalpa to determine whether C. speciosa or C. bignonioides was a parent. Structural characters peculiar to $\mathrm{C}$. bignonioides were found, hence it was inferred that this species was a parent. The other parent, C. Kaemferi,

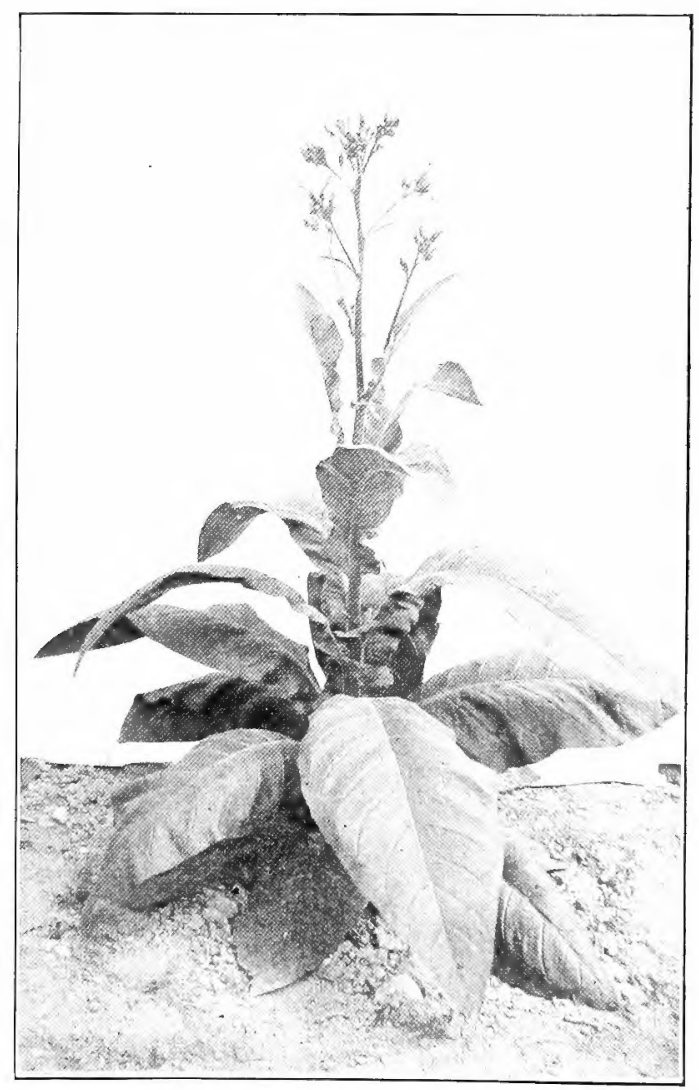

Fig. 1.-Nicotiana Tabacum. 
was dominant in most of the external characters of the hylrid, and a study of internal strueture showed a dominance of this species there also.

Groth $(1911,1912)$, after an cxtended study of the form and structure of hrbrids between sereral variotics of tomatoes, concluded: "Practically all the characters studied tend to cxeced the mean between the values of the parents, in the $F_{1}$ of the cross, so that the leaves of the cross tend to be lomecr, narrower, and posicss a creater number of segments than the mean between the values for the parents, or even than either of the parents themselves. In other words, the crosses tend to be more vigorous than the parcnts." Further, he concludes: "Reciprocal and duplicate crosscs usually agree in the inheritance of all characters studied; but they may differ greatly. Even plants borne from the seed of one fruit pollinated by pollen from a single flower may differ radically in characters of size, shape and number."

Cannon (1909), made a stuly of the trichomes of eleven different species and hybrids of Juglans. Oemothera, Papaver and Solanum

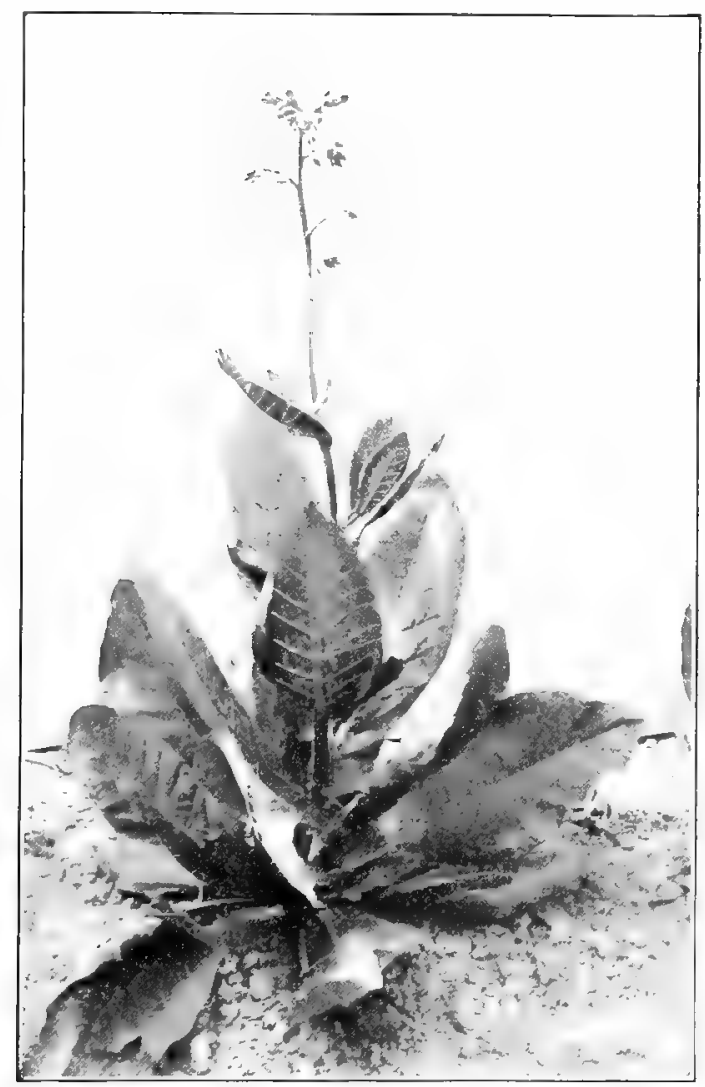

Fig. 2.-Nicotiana sylvestris. 

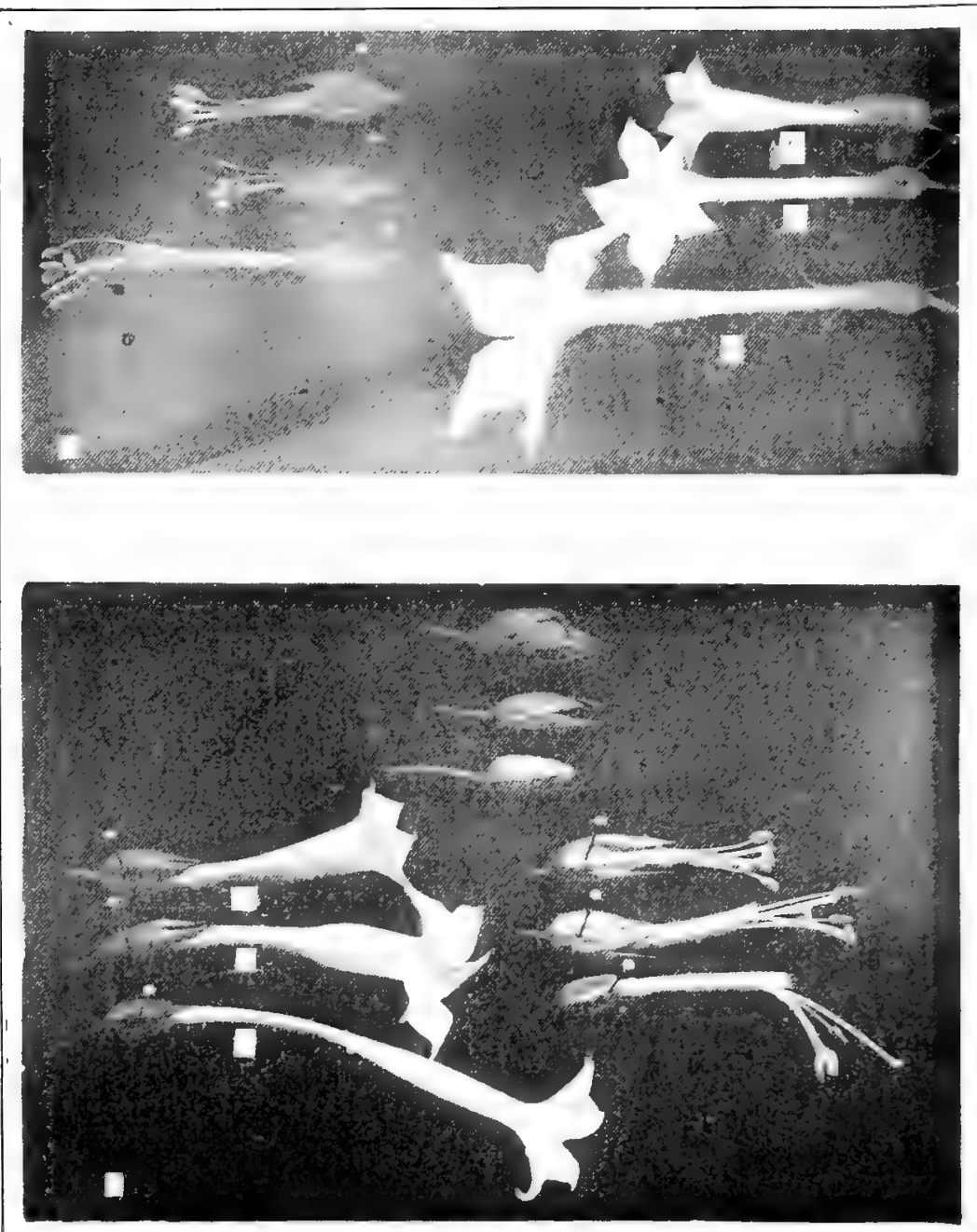

Fig. 4.-Flowers and flower parts of; (a.) Nicotiana alata: (b.) N. Tabacum: (c.) Hybrid.

Fig. 5.-Flowers and flower parts of; (a.) N. Tabacum: (b.) N. sylvestris: (c.) Hybrid.

which represcnted a considerable range of life conditions as well as types of variation. Oenothera hybrids were found to inherit characters from foth parents but only one type of trichome was found which had an internodiate structural character. In Juglans, first and second hybrid generations showed intermediate leaf characters and each hybrid was found to bear all the different types of trichomes found in both parents. 


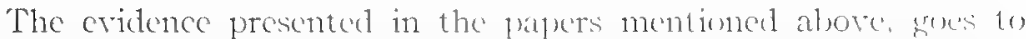
show that, in general, the structural characters of hybrids atre intermediate between those of their parents; yet, in some cases as pointert out by MacFarlane ('91-a.) there is a decided leaning toward one or the other of the two parents. In other cases there is a complete dem?inance over certain characters as shown by Furmer ('97) in Polyoxdium Schneideri, or dominance of one parent over the hybrid in the midority of its characters as shown by Penhallow (1905) in the hylorid Catalya (C. bignonioides x C. Kacméri).

In but few of the papers were the parent and hybrid characters tabulated or summarized, so that a seneral comparison crulel be made: and but slight attention was given to the relation of external and histological characters.

\section{Hybrid Nicotianas.}

Vicotiana Tabacum, var. Haiana, a varioty common in cultivation, was used as a pistillate parent in two crosses. (See figs. 1 and 4 .)

Vicotiana sylzestris and $N$. alata, flowering tobacess. were userl as staminate parents in the two crosises with $\mathrm{N}$. Tabacum. (For $\mathrm{N}$. sylvestris, see figs. 2 and 4 ; and for $\mathbf{N}$. alata, see figs 5 ant 7 .)

\section{Nicotiana Tabacum $x \mathbf{N}$. sylvestris.}

Plants tall, slender, erect, rigrous, 13-18 1m. tall; (ntire plant viscid pubessent; upper leaves asonding, auriculate-sate, clasping

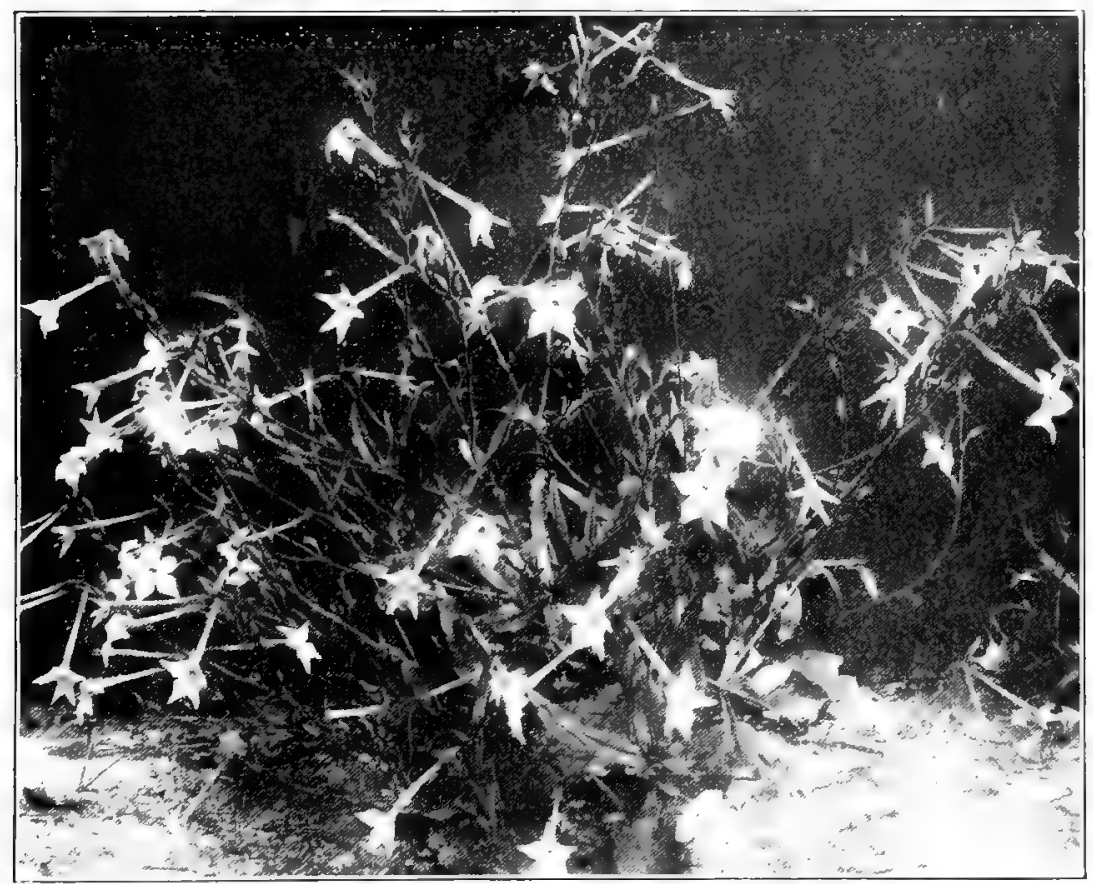

Fig. 7.-Nicotiana a!ate 


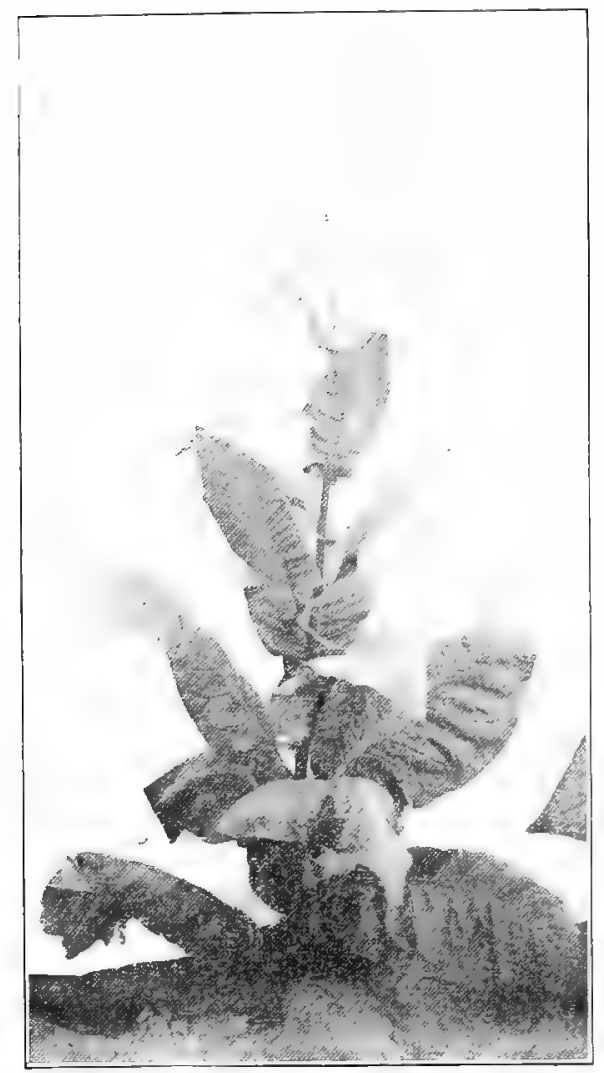

Fig. 3.-Nicotiana Tabacum

$x$

Nicotiana sylvestris

acuminate at apex, $3-8 \mathrm{dm}$. long, $1-4 \mathrm{dm}$. wide; stem nearly straight, crlindrical, cnlarged slightly at the base of cach of the soveral lateral branches, $2-4 \mathrm{~cm}$. in diam. $30 \mathrm{~cm}$. abore ground; springing from the end of the stem $4-8 \mathrm{~cm}$. below the surface of the ground are num rous roots, each smonth, eylindrical, 2 - 3 dm. long, and about $1 \mathrm{~cm}$. thick. Flowers in a larue dense panicle, numerous throughout the whole season; corolla salver furm, tube $6 \mathrm{~cm}$. lung, alsuptly cnlarged above, the lobes large and sjorcarling, so large that there is not room enough in the circle for them to srread out, hence they are somewhat fluted and pushed out of place: spread of corolla lobes $3.5-3.8 \mathrm{~cm}$; color, light pink; calyx samoseralous with 5 cuneate teeth $10-12 \mathrm{~mm}$. long, tube 12 mm. long; stamens 5 , attached to corolla tube near its base; anthers 4.5 - $5 \mathrm{~mm}$. long, oblong, enlarged slightly toward the base, $2 \mathrm{~mm}$. thick. Pollen defective. Stigma calitate, 2 lobed, style filiform, $4.5-5 \mathrm{~cm}$. long; orary conical, $4 \mathrm{~mm}$. wide, and $8 \mathrm{~mm}$. long; capsules 
for, small, irregrtar and shriveled with an occasional sere. (Sice figs. 3, 5c. and (ic.)

The Tabaum x sylyestris hybrids are thrifty plants, larger than cither parent and remarkably uniform in size, and alpearance. They are intermediate between the two parents in eertain ways, but in the main the characters of the pistillate parcnt, Nicotiana tabacum, are dominant. The hybrids, as stated above, are taller than either parent, heing fire to six fect in heirht, while $N$. Tabacum is thrce and onehalf to four foct, and N. sylvestris four to four and on -half feet high. The general habit of the plant and the form of the infloresecnee resembles $N$. sylvestris rather closely (firs. 1, 2, 3), but the leaves are mor like $N$. Tabacum leares. They are large, acuminate, rugose, and rather abundant high up on the stem; they have about the same thickness as $N$. sylrestris leares, and are slightly more ascending than in $\therefore$. Tabacum.

The flowers do not resemble those of either parent very closely (fir. 5). They are light-pink, mostly not quite so dark as the $N$. Tabacum flowers. The lobes of the corolla have a tendency to be irregular; both parents have regtlar corollas. The spread of the corolla is greater thon that of either parent and the tube wider; the tube is lomger than in $\mathrm{N}$. Tahacum, but shorter than in $\mathrm{N}$. stlvestris. The form

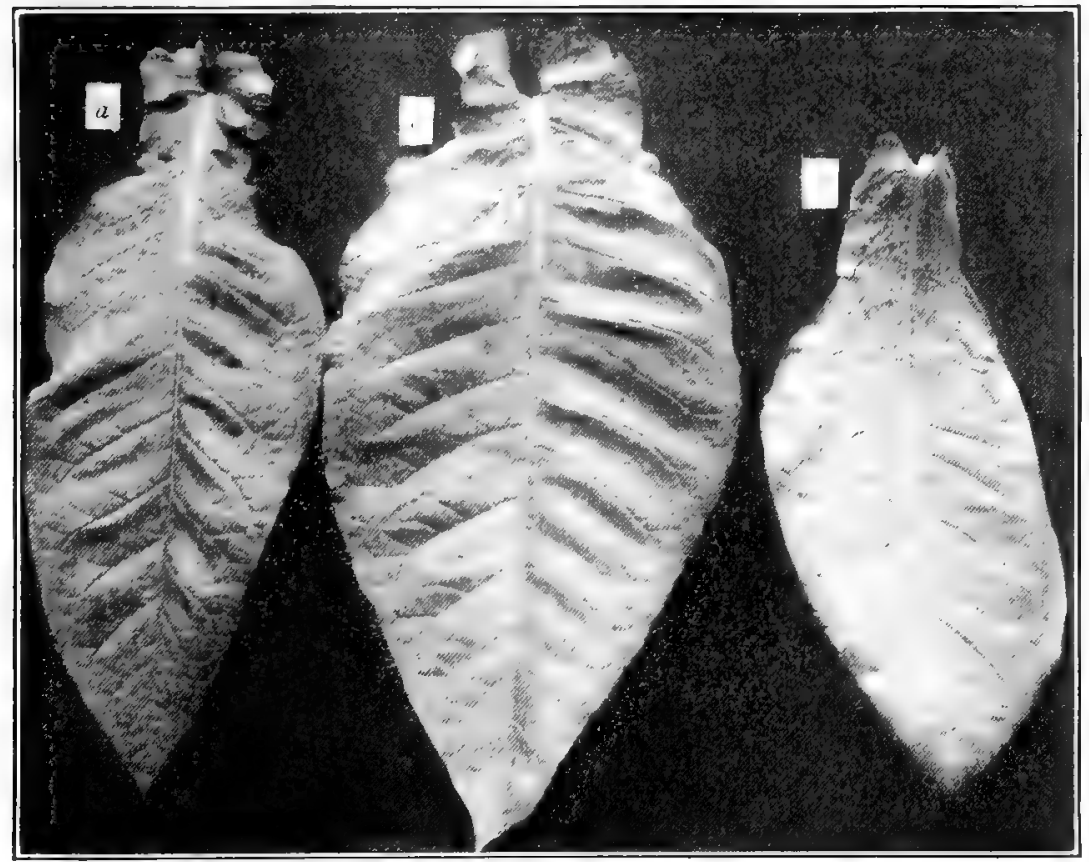

Fig. 6.-Leaves of

A. N. Tabacum

B. N. sylvestris

C. Hybrid 
and size of the calyx is intermediate between the same of the two parents, as is also the length of the stamens and shape and size of the anthers. The seed pods, in so far as they develop, seem to be intermediate in size and form. They become shriveled and contain but few seeds. The majority of the flowers set no seed at all; this is due to the lack of pollen, only a small quantity being produced, and this consists nearly altogether of defective, shriveled grains.

This cross was repeated in 1909 and the hybrids produced were, apparently, similar to the ones described.

\section{Nicotianz Tabacum, N. sylvestris and Hybrid.}

HISTOLOGICAL STRUCTLRE.

STEMs. (Cross section of stem of each $30 \mathrm{~cm}$. above ground).

The cortex is comparatively thick in each of the three plants; in N. Tabacum the entire thickness (extending from the outside to cambium), is $1055 \mu$; in N. sylvestris it is $945 \mu$ thick and in the hybrid $1350 \mu$. The main portion of the cortex consists, in each case, of thin walled parenchyma cells rather locsely united. The number of large thin walled parenchyma cells is somewhat greater in N. Tabacum, and in the hybrid than in $\mathrm{N}$. sylvestris; these cells average somewhat larger in the hybrid than in $\mathrm{N}$. Tabacum (figs 9,10 and 11). The number of layers of cortical cells is abou't the same in the three plants. The nuclei of these cells are about the same size in N. Tabacum and $\mathrm{N}$. sylvestris, - being about $15-17 \mu$ in diam., while in the hybrid cells they seemed to vary in size, ranging from $12-24 \mu$ in diam.

In the inner part of the cortex of each, are strands of bast fibers. In $\mathrm{N}$. sylvestris, these fibers are in clusters of 4 to 20 , and the clusters are so numerous that they form a nearly continuous band around the stem. The average diameter of each fiber is $\tilde{5} 4 \mu$, the cell wall being about $4 \mu$ thick on the average. In N. Tabacum, these clusters are more scattered and only 2 to 10 in a cluster; the average width of each fiber is $42 \mu$, while the average thickness of the cell wall is about $10 \mu$. In some fibers the lumen is practically absent, while in the fibers of the $\mathrm{N}$. sylvestris there is a comparatively large lumen in each fiber. In the hybrid, there are scattered clusters about the same as in $\mathrm{N}$. Tabacum; average width of each fiber is $60_{\mu}$, wall thickness $9_{\mu}$. These fibers are slightly larger than the fibers of the staminate parent, $\mathrm{N}$. sylvestris, while they have a wall thickness about the same as the fibers in the pistillate parent. However, in the hybrid they vary in size considerably more than in either parent.

Phloem: In each of the three plants the phloem strands are small and not very distinct from the neighboring cells of the inner part of the cortex. However, rather large sieve tubes and small companion cells can be identified. In $\mathrm{N}$. Tabacum, the sieve tubes are from $18-24 \mu$ in diameter, and in $N$. sylvestris $15-21 \mu$. In the hybrid they are about the same size as in N. Tabacum.

XYLEM: The xylem or wood of the stem is well developed in each of the three plants. In N. sylvestris, it is about $1600 \mu$ thick, in 
N. Tabacum about $2000 \mu$, and in the hybrid about $2,600 \mu$. It is made up principally of tracheids of rather uniform size; scattered among these are rows of large pitted vessels, together with a few small spiral and annular vessels. Between the xylem strands are numerous medullary rays (figs. 7, 10 and 11). The pitted vessols average about $65 \mu$ in diameter in N. Tabacum, $50 \mu$ in $\mathrm{N}$. sylvestris, and $80 \mu$ in the hybrid. (Longitudinal sections were used only in identifying the elements of the tissues.) The tracheids are about $20 \mu$ wide in $\mathrm{N}$. Tabacum, $19 \mu$ in N. sylvestris, and $30 \mu$ in the hybrid. The walls of the tracheids are $2.5_{\mu}$ thick in N. Tabacum, $1.5 \mu$ thick in N. slyvestris, and about $2.2_{\mu}$ thick in the hybrid. The medullary ray cells are about the same size in the two parents, $18 \mu$ wide and $45 \mu$ long, but in the cross, they are considerably larger, being about $30 \mu$ wide and $60 \mu$ long.

The central part of the stem in each plant contains a comparatively large mass of pith tissue; this is made up of large, thin-walled parenchyma cells. These cells are large and sub-spherical in each of the three plants, being about 150 to $230 \mu$ in diameter in N. Tabacum, 107 to $230 \mu$ in N. sylvestris, and 275 to $460 \mu$ in the hybrid.

In the outer portion of the pith are small clusters of fibers similar to the bast fibers discussed above. They are found here in each plant in about the same proportion as in the bast, and the individual fibers have about the same relative size.

Roots: Each plant possesses several rather large cylindrical roots, each being .6 to $1 \mathrm{~cm}$. in diameter, and of a nearly uniform diameter for a length of $20 \mathrm{~cm}$. or more. The structure of the roots of the three plants, compared, presents no very important differences. Each has a comparatively thick cortex made up of thin-walled parenchyma cells. These cells are well filled with starch. The cortex in N. sylvestris is about $1050 \mu$ thick, $1,200 \mu$ in N. Tabacum and $1325 \mu$ in the hybrid. The central part of the roots is made up of woody tissue. This tissue consists of rather large pitted vessels, tracheids and numerous medullary rays, the last forming one-third to one-half of the tissue of this part of the root. The medullary ray cells are richly stored with starch. The vessels are $45-105 \mu$ in diameter in N. sylvestris, $60-135 \mu$ in N. Tabacum and $75-135 \mu$ in the hybrid. The walls of the tracheid cells are $2 \mu$ thick in N. sylvestris, $3.5 \mu$ thick in N. Tabacum, and $2.5 \mu$ thick in the hybrid.

Starch Grains: In N. Tabacum the simple grains are circular in outline (fig. 27); in N. sylvestris they are elongated considerably, many appearing elliptical to ovate in outline and they averaged considerably larger than in N. Tabactum (fig. 29). In the hybrid there are grains of both shapes, circular ones predominating, and the grains are much larger than in either parent (fig. 28).

Leaf Structure: As stated above, the N. Tabacum leaves are considerably thicker than the leaves of either of the other two plants under comparison. In $\mathrm{N}$. Tabacum they are $330-370_{\mu}$ thick, $225-$ $270 \mu$ in N. sylvestris, and 225 to $285 \mu$ in Tabacum x sylvestris (figs. 24,25 and 26). The palisade cells in N. Tabacum are regular and about $140 \mu$ long; in $\mathrm{N}$. sylvestris they are somewhat more irregular, 
and are about $76 \mu$ long; in the hybrid, they are about the same as in $\mathrm{N}$. sylvestris. The spongy parenchyma in each of the three plants is made up of loosely connected cells with numerous large intercellular spaces; $N$. sylvestris and the hybrid have about the same amount, while $N$. Tabacum has somewhat more. The epidermal cells vary considerably in size and shape in each plant, but no important differences between the different species were noted. There are epidermal hairs on both sides of the leaves on all three of the plants, and stomates on both sides also, being slightly more on the under side; these were practically the same in the different species.

The leaf mid-rib was sectioned and studied but the results obtained were not very satisfactory. There seems to be considerable difference in the structure of the mid-rib in the two parent species, but since the structure in one species varies considerably with a slight difference in age and position it was not possible to make satisfactory comparisons. However, the mid-ribs of the hybrid showed an intermediate structure in so far as could be determined.

Anthers: As was mentioned above, the anthers of N. Tabacum are considerably thicker than those of $\mathrm{N}$. sylvestris (figs. 14, 15, and 30), but not so long, while the anthers of the hybrid are intermediate in both thickness and length. The epidermal cells are papillose in each of the three and similar. The outer wall of the loculus is made up principally of large parenchyma cells with spiral or band-like thickenings in their walls. In $\mathrm{N}$. sylvestris, for most of the distance along the loculus, there is only one layer of these large cells, and one to two rows of smaller ones; in $\mathrm{N}$. Tabacum there are two or more layers of the larger ribbed cells, and some smaller ones. In the hybrid, these cells are similar to the corresponding cells in the pistillate parent, both in number and size.

The placenta-like outgrowth extending out into each cell of the anther is really a modification of the wall that formerly separated the loculi. This growth varied considerably in different anthers in the same species, but as a rule, it was larger in anther cells of the hybrid, where there was not much pollen. The pollen grains are spherical in both parent species and $24 \mu$ in diam. In the hybrid they are nearly all shriveled and defective, merely the collapsed cell wall being present.

Calyx: Cross sections of the ovaries of each of the plants under comparison were made, together with sections of the calyx and corolla surrounding. From these sections the ones passing through the thickest part of the ovary were chosen for comparison.

In $N$. sylvestris, the calyx averages about $225 \mu$ in thickness, in $\mathrm{N}$. Tabacum it is about $255 \mu$ thick and in the hybrid $225 \mu$. Intercellular spaces are not so abundant in the calyx of $\mathrm{N}$. sylvestris as in the other two species.

Corolla: The corolla of $\mathrm{N}$. sylvestris sectioned as mentioned above, showed a thickness of $220 \mu, \mathrm{N}$. Tabacum corolla $412 \mu$, and the hybrid $330 \mu$. The corolla of $\mathrm{N}$. Tabacum where sectioned, is made up chiefly of parenchyma cells fitting together closely. A corresponding section of $\mathrm{N}$. sylvestris corolla showed cells very loosely joined, while the 
hybrid showed an intermediate structure with a leaning toward the pistillate parent. The epidermal cells both on the inner and outer side of the corolla tube, are palisade-like in form and arrangement, in each of the three species, but they are slightly different in the two parent species being more narrow and somewhat longer in N. Tabacum. In the hybrid they are similar to the ones in the pistillate parent.

Ovary: The ovary of N. Tabacum is considerably thicker than the ovary of N. sylvestris (figs. 19 and 21), while the ovary of the hybrid, with the exception of being slightly larger, is very similar to that of $\mathrm{N}$. sylvestris. In $\mathrm{N}$. sylvestris, the thickness of the ovary wall is about $90 \mu$, and the partition dividing the two cells has about the same thickness; in N. Tabacum, the ovary wall is $105 \mu$ thick and the partition $150 \mu$; in the hybrid the wall is about $105 \mu$ thick, and the partition $130 \mu$. The form of the placenta varies greatly in sections cut in different parts of the ovary.

In the following tables the main morphological and histological characters of parents and hybrid are brought together, in order that they may be compared easily. The ratio of inheritance of individual characters, also the sum total of characters, is expressed in per cent. The only characters listed are those which differed in the two parents. 


\section{Nicotiana Tabacum, N. sylvestris and Hybrid.}

EXTERNAL CHARACTERS TABULATED.

\begin{tabular}{|c|c|c|}
\hline$\cdot$ & N. TABACUM. & HYBRID. \\
\hline Av. height, & 11 dc., & $15.5 \mathrm{dc}$. \\
\hline $\begin{array}{l}\text { Distribution of leaves on } \\
\text { stem, }\end{array}$ & On lower 3-5, & On lower 3-5. \\
\hline Habit of leaves, & Spreading, & Spreading to ascending. \\
\hline Shape of leaves, & Ovate-lanceolate, & Ovate-1anceolate. \\
\hline Base of leaf, & Auriculate, clasping, & Auriculate, clasping. \\
\hline Tip of leaf, & Acuminate, & Acuminate. \\
\hline Thickness of leaf, & $350 \mu$ & $255 \mu$ \\
\hline $\begin{array}{c}\text { Thickness of stem } 30 \mathrm{~cm} \text {. } \\
\text { above ground, }\end{array}$ & $2.5 \mathrm{~cm}$. & $2.9 \mathrm{~cm}$ \\
\hline Inflorescence, & Panicle, & Rather dense panicle. \\
\hline Length of calyx, & 2. $\mathrm{cm}$., & $2.4 \mathrm{~cm}$ \\
\hline Length of corolla tube, & $4.5 \mathrm{~cm}$. & 6. $\mathrm{cm}$ \\
\hline $\begin{array}{l}\text { Thickness of corolla tube, } \\
\text { narrow part, }\end{array}$ & $.4 \mathrm{~cm}$. & $.45 \mathrm{~cm}$ \\
\hline Shape of corolla, & Narrowly funnel-form, & $\begin{array}{l}\text { Salver form to slightly } \\
\text { funnel-form. }\end{array}$ \\
\hline Color of corolla, & Pink, & Light pink. \\
\hline Length of anthers, & $.45 \mathrm{~cm}$. & $.48 \mathrm{~cm}$ \\
\hline Thickness of anthers, & $.25 \mathrm{~cm}$. & $.2 \mathrm{~cm}$ \\
\hline Length of ovary, & $.65 \mathrm{~cm}$. & $.8 \mathrm{~cm}$ \\
\hline Length of seeds, & $.0712 \mathrm{~cm}$ & $.0730 \mathrm{~cm}$ \\
\hline Wirlth of seeds, & $.0517 \mathrm{~cm}$ & $.051 \mathrm{~cm}$ \\
\hline \multicolumn{3}{|l|}{ Total, } \\
\hline Reduced to ner cent., & & \\
\hline
\end{tabular}


Nicotiana Tabacum, N. splvestris and Hybrid.

EXTERNAL CHARACTERS TABLLLATED.

\begin{tabular}{|c|c|c|}
\hline ‥ SyLvestris. & $\overparen{C}$ N. TABACUM. & $\%$ N. SYLVestris. \\
\hline $12 \mathrm{dm}$. & 43.8 & 56.2. \\
\hline On lower $1 / 2$, & 90.0 & 10.0 \\
\hline Ascending, & 50.0 & 50.0 \\
\hline Elliptical-ovate, & 90.0 & 10.0 . \\
\hline $\begin{array}{c}\text { Somewhat clasping, slight- } \\
\text { ly auriculate, }\end{array}$ & 100.0 & 0.0 \\
\hline Bluntly acute, & 100.0 & 0.0 \\
\hline $24 \delta \mu$ & 6.8 & $9: 3.2$. \\
\hline $1.5 \mathrm{~cm}$. & 88.8 & 22.2 \\
\hline $\begin{array}{l}\text { Flowers in whorls or fasci- } \\
\text { cles in a dense panicle, }\end{array}$ & 30.0 & 70.0 \\
\hline $1.5 \mathrm{~cm}$. & 69.3 & 30.7 \\
\hline 8. $\mathrm{cm}$. & 57.2 & $42 \times$ \\
\hline $.2 \mathrm{~cm}$. & 83.4 & 16.6. \\
\hline Salver form to funnel form, & 50.0 & 50.0 \\
\hline White, & 60.0 & 40.0 \\
\hline $.5 \mathrm{~cm}$. & 40.0 & 60.0 \\
\hline $.15 \mathrm{~cm}$. & 50.0 & 50.0 \\
\hline $.6 \mathrm{~cm}$. & 57.2 & 42.8 \\
\hline $.065 \mathrm{~cm}$. & 81.7, & $1 \rightarrow 3$ \\
\hline \multirow[t]{3}{*}{$.036 \mathrm{~cm}}$. & 95.6 & 4.4. \\
\hline & 1243.8 & 667.2. \\
\hline & 64.6. & $35+$ \\
\hline
\end{tabular}




\section{Nicotiana Tabacum, N. sylvestris and Hybrid.}

HISTOLOGICAL CHARACTERS TABULATED.

\begin{tabular}{|c|c|c|}
\hline Characters. & N. TABACUM. & HyBRID. \\
\hline Thickness of cortex, & $1055 \mu$ & $1350 \mu$ \\
\hline Number of bast fibers, & Rather numerous, & Rather numerous. \\
\hline Diameter of bast fibers, & $42 \mu$ & $60 \mu$ \\
\hline Thickness of wall of fibers, & $10 \mu$ & $9 \mu$. \\
\hline Thickness of wood, & $2000 \mu$ & $2600 \mu$. \\
\hline Diameter of xylem vessels, & $65 \mu$ & $80 \mu$ \\
\hline $\begin{array}{l}\text { Liameter of tracheids in xylem } \\
\text { of stem, }\end{array}$ & $20 \mu$ & $30 \mu$ \\
\hline $\begin{array}{l}\text { Thickness of tracheid wall in } \\
\text { xylem of stem, }\end{array}$ & $2.5 \mu$ & $2.2 \mu$ \\
\hline Diameter of seive tubes of stem, & $21 \mu$ & $21 \mu$ \\
\hline Thickness of cortex in roots, & $1200 \mu$ & $1325 \mu$ \\
\hline Diameter of vessels in root, & $98 \mu$ & $105 \mu$ \\
\hline $\begin{array}{c}\text { Thickness of wall of root } \\
\text { tracheids, }\end{array}$ & $3.5 \mu$ & $2.5 \mu$ \\
\hline Length of palisade cells of leaf, & $140 \mu$ & $76 \mu$ \\
\hline Cells in wall of loculus of anther. & 2 rows large cells, & 2 rows rather large cells \\
\hline Thickness of calyx, & $255 \mu$ & $225 \mu$ \\
\hline Intercellular spaces in calyx, & Numerous, & Numerous. \\
\hline Thickness of corolla, & $412 \mu$ & $330 \mu$ \\
\hline Shortest diameter of ovary, & $2900 \mu$ & $2500 \mu$ \\
\hline Thickness of ovary wall, - & $105 \mu$ & $105 \mu$ \\
\hline $\begin{array}{l}\text { Thickness of partition wall of } \\
\text { ovary, }\end{array}$ & $150 \mu$ & $150 \mu$. \\
\hline \multicolumn{3}{|l|}{ Total, } \\
\hline Refured to ner cent.., & & \\
\hline
\end{tabular}


Nicotiana Tabacum, N. sylvestris and Hybrid. HISTOLOGICAL CHARACTERS TABULATED.

\begin{tabular}{|c|c|c|}
\hline N. Sylvestris. & $\stackrel{C N}{C}$ TABACLM. & r. S. Sylvestris. \\
\hline $945 \mu, \quad \forall,: \ldots$ & 67.5, & 32.5 \\
\hline Numerous, & 70.0 & 30.0 \\
\hline $54 \mu$ & 25.0 & 75.0 \\
\hline $4 \mu$ & 83.4, & 16.6 . \\
\hline $1600 \mu$, & 62.5 & 37.5 \\
\hline $50 \mu$ & 66.7 & 33.3. \\
\hline $19 \mu$ & 52.4 & 47.6. \\
\hline $1.5 \mu$ & 70.0 & 30.0 \\
\hline $1 \curlyvee . \mu$. & 100.0 & 00.0 \\
\hline $1050 \mu$ & 68.8 & 31.2. \\
\hline $7.5 \mu$ & 81.1 & 1 ร. 9. \\
\hline $2 \mu$ & 33.3 & 66.7 \\
\hline $76.5 \mu$ & .7 & 99.3 \\
\hline 1 row of large cells, & 90.0 & 10.0 \\
\hline $225 \mu$ & 0.0 & 100. \\
\hline Nrt numerous, & 100.0 & 0.0 \\
\hline $220 \mu_{\mu}$ & 57.2 & 42.8 \\
\hline $2100 \mu$ & 20.0 & 80.0 \\
\hline $90 \mu$ & 100.0, & 0.0 \\
\hline \multirow[t]{3}{*}{$90 \mu$} & 100.0 & 0.0 . \\
\hline & 1248.6 & 751.4. \\
\hline & 61.9 & 38.1. \\
\hline
\end{tabular}


From the above discussion and tables, it will be seen that the pistillate parent influenced the external characters of the hybrid to the extent of $64.6 \%$, and the internal or microscopic characters $61.9 \%$. The staminate parent had influence to the extent of $35.4 \%$ and $38.1 \%$ respectively.

Among the external characters, there were only two over which the pistillate parent had pure dominance, while the staminate parent did not have complete dominance over any. Of the ninteen characters compared, seventeen were intermediate. Among the microscopical characters, the pistillate parent had pure dominance over four, and the staminate parent over one; sixteen of the twenty-one characters compared, were intermediate.

In these plants it seems that there is a close relationship between external and internal characters, the parent having the most influence over one, has a correspondingly greater influence over the other. The extra size of the hybrid is produced by the largeness of its cells over the corresponding cells of its parents (see table of microscopical characters), rather than by a multiplication of cells.

\section{Nicotíana Tabacum, N. alata and Hybrid.}

\section{EXTERNAL CHARACTERS.}

Nicotiana Tabacum and $\mathrm{N}$. alata were referred to in the preceding pages. The hybrid, $\mathrm{N}$. Tabacum $\mathrm{x}$. alata, is a slender, dwarfed plant (fig. 8), height $40 \mathrm{~cm}$., leaves few; linear-lanceolate, undulate, sessile, $10 \mathrm{~cm}$. long, $2.5 \mathrm{~cm}$. wide; stem straight, cylindrical, $1.5 \mathrm{~cm}$. thick; flowers sparse in 3 or 4 terminal racemes; gamosepalous, tube $10 \mathrm{~mm}$. long, 10 nerved, 5 teeth, linear subulate, $12-14 \mathrm{~mm}$. long, spreading at tip; corolla gamopetalous, salverform, tube $6.5 \mathrm{~cm}$. long, enlarged abruptly a few millimeters below the spreading lobes; lobes regular, somewhat orbicular with a short acuminate tip; spread of lobes $4.2 \mathrm{~cm}$.; corolla, light pink in color, with green veins on outside; stamens five, attached to the corolla tube toward the base, four as long as the pistil, and one shorter; anthers brownish purple, $3.5 \mathrm{~mm}$. long, $2 \mathrm{~mm}$. wide; filaments filiform without thickening in the middle as in N. alata; style $6 \mathrm{~mm}$. long, filiform, stigma capitate, 2 lobed, ovary conical. No fruit set, ovaries falling soon after the blossoms closed. Pollen scarce, and grains nearly all shriveled and defective (fig. 4c).

The hybrid above described was a dwarf in comparison with its parents, being smaller than either. It possessed certain characters of each parent, but resembled the staminate parent in the main. The form of the stem and branches was intermediate,- - the main stem not being so pronounced as in N. Tabacum, but more so than in N. alata, while the lateral branches were smaller and fewer than in N. alata. The leaves were very small; smaller than the leaves on either parent, but they had a shape much like N. alata leaves. The flowers were intermediate in size, shape and color. 


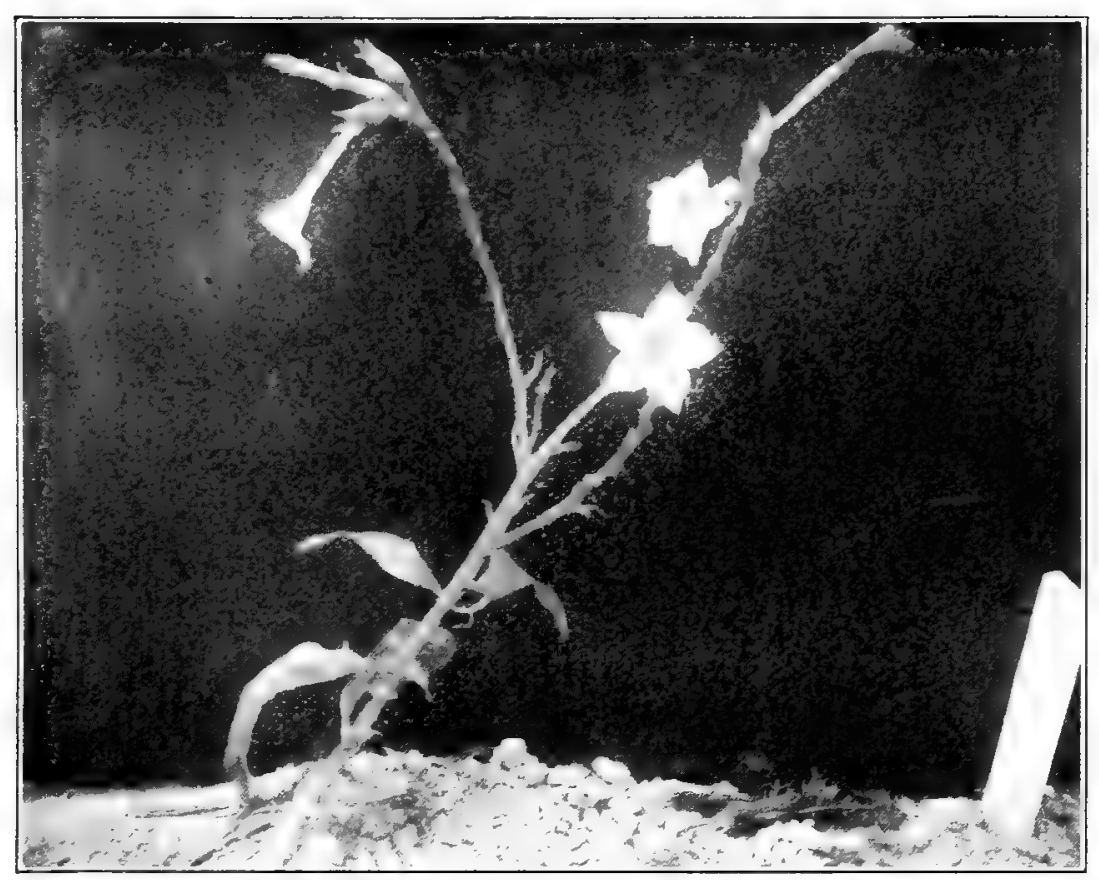

Fig. 8.-Nicotiana Tabacum

Nicotiana alata

Nicotiana Tabacum, N, alata and Hybríd.

HISTOLOGICAL CHARICTERS.

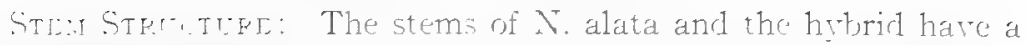

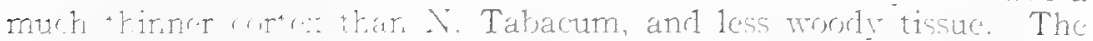

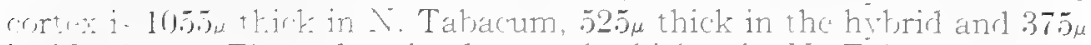

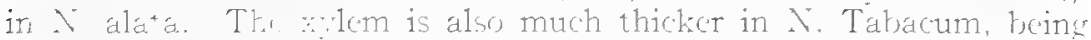

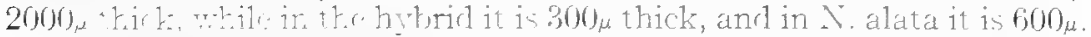

The o, idterriel w 11: if the stem vary considerat)ly in the three

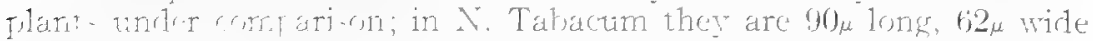

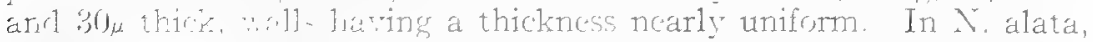
the epidermal colls are about $70 \mu$ 1rong, $33 \mu$ wide, and $27 \mu$ thick; they

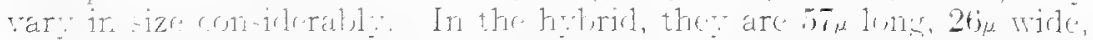

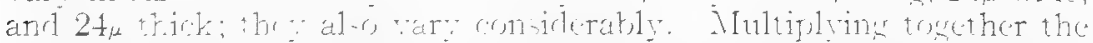

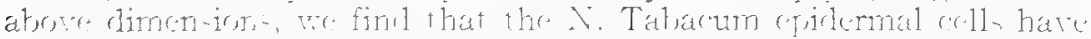

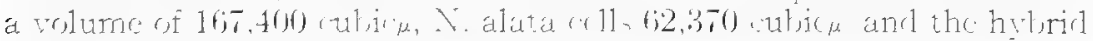

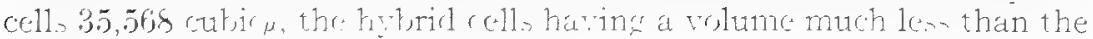
corresponding cells of either parent.

In $X$. Tatacum, the first two or three layers of cells beneath the epidermis are globular in shape, and are very similar to other cortical cells, excerst that they are more richly supplicd with chloroplastids. 
In N. alata, the first layers of hypodermal cells are decidedly different from underlying cortical cells. They are well supplied with chloroplastids and simulate the mesophyll of leaves in appearance, the first layer being made up of cells more or less cylindrical, and arranged in palisade fashion, while the cells just under these are shorter and loosely joined. They may be compared to the spongy parenchyma of leaves. (Fig. 12.) The corresponding cells in the hybrid are intermediate; the first layer has rather large cells, and they are somewhat palisade in form and arrangement, but they fit together closely. The next layers under this are similar to cortical cells, and have no large intercellular spaces. The bast fibers in N. Tabacum average $42 \mu$ in diameter and the cell wall is $10 \mu$ thick; in N. alata the fibers average about $55 \mu$ in diamater with a wall thickness of $3 \mu$; in the hybrid the fibers are of two sorts, some about $60 \mu$ in diameter with a wall $3 \mu$ thick, other; being about $28 \mu$ in diameter, and having a wall $4.5 \mu$ thick. The larger ones resemble $N$. alata bast fibers, rather closely, while the small ones are much like bast fibers found in the other parent.

The xylem vessels of $\mathrm{N}$. Tabacum are $65 \mu$ in diameter, in $\mathrm{N}$. alata they are $45 \mu$, and in the hybrid, about $35 \mu$; tracheid cells are respectively 20,18 , and $22 \mu$ in diameter.

The medullary rays, in the sections of $\mathrm{N}$. alata and hybrid examined, were not clearly differentiated, while in N. Tabacum they ware. In this species the ray cells have thin cellulose walls in marked contrast to the lignified tracheids and xylem vessels (figs 9, 12 and 13).

The pith cells are large, thin-walled, sub-spherical cells in each of the three plants; in N. Tabacum they are $150-230 \mu$ in diameter; in N. alata $120-222 \mu$, and in the hybrid $100-150 \mu$. The nuclei of the pith cells are very prominent; they vary in size considerably in a single species, but are considerably larger on the average in $\mathrm{N}$. Tabacum than in the other plants compared; in N. Tabacum they are from $12-30 \mu$ in diameter, $9-21 \mu$ in N. alata, and $7-12 \mu$ in the hybrid.

In the periphery of the pith of the stem, are a few fibers in each; these are similar to the bast fibers found in the same species. They are scarce in N. alata and rather plentiful in N. Tabacum and the hybrid.

LEAVES: The leaves of the three plants have about the same thickness and are very similar in structure. They all have stomates on both sides, being more numerous on the under side in each case. All three have hairs on both sides of the leaves; these are about the same in size and quantity.

ANTHERS: The anthers of both parents are considerably larger than those of the hybrid; in N. Tabacum they are $2220 \mu$ rride (widest part), $2850 \mu$ in N. alata and $2025 \mu$ in the hybrid. The anthers of the two parents differ considerably in shape, the anthers of N. Tabacum appearing in cross-section somewhat like a butterfly with wings spread (figs. 30,31 , and 32 ), while the cross sections of $\mathrm{N}$. alata anthers look like cross-sections of two parallel cylinders that are slightly connected laterally.

The wall surrounding the anther loculi is different in the two parent species. In $\mathrm{N}$. Tabacum, it has in its central part, two or more layers 
of large cells with thickened bars in their walls; $N$. alata has but one layer of those large cells around a considerable part of its wall, but there are about two layers of small cuboidal cells within this layer; N. Tabacum does not have these cuboidal cells clearly defined. The loculus wall of the anthers of the hybrid is rather intermediate; although there are not quite so many cells, it has rows of large, ribbed cells similar to $N$. Tabacum, while the small cuboidal cells on the inside are rather prominent.

Pollen grains in N. Tabacum are $24 \mu$ in diameter, and nearly spherical; in N. alata they are about $30 \mu$ in diameter, and are slightly angular, many appearing obtusely triangular in section; the pollen grains of the hybrid are nearly all small, shriveled, and defective. The few that were nearly perfect were about spherical and had a diameter of $27-30 \mu$.

OVARIES: Excepting some difference in size, the ovaries of the three plants are similar in structure and general arrangement of parts.

Corolla: (Cross sections of the part of the corolla tube surrounding the ovary were used.) The sections of $\mathrm{N}$. Tabacum are $412 \mu$ in thickness. The epidermal cells on either side of these sections are palisade in form, $39 \mu$ long and $13 \mu$ wide; the cells in the central part of the section are spherical and fit together closely. The calyx of $N$. Tabacum is $225 \mu$ thick (fig. 21 ). N. alata has a corolla $270 \mu$ thick, the epidermal cells being decidedly palisade in form and arrangement, and are about $57 \mu$ long and $24 \mu$ wide; the mesophyll cells are loosely joined. The calyx is $217 \mu$ thick. It has a layer of peculiar thick-walled lignified cells just beneath the inner epidermal cells. These cells are about $1.5 \mu$ long and vary considerably in width, the majority being about $6 \mu$ wide (fig. 17).

In N. Tabacum $\times$ N. alata, the corolla is $210 \mu$ thick, epidermal cells palisade, $45 \mu$ long on the outside of corolla and $33 \mu$ long on the inside. The mesophyll cells are rather closely joined. The structure of the corolla is very similar to that of $\mathrm{N}$. Tabacum, but in thickness it is more like $N$. alata. The calyx is $250 \mu$ thick, and has a layer of sub-epidermal thick-walled cells of the same character, size and shape as in $\mathrm{N}$. alata (fig. 19). 


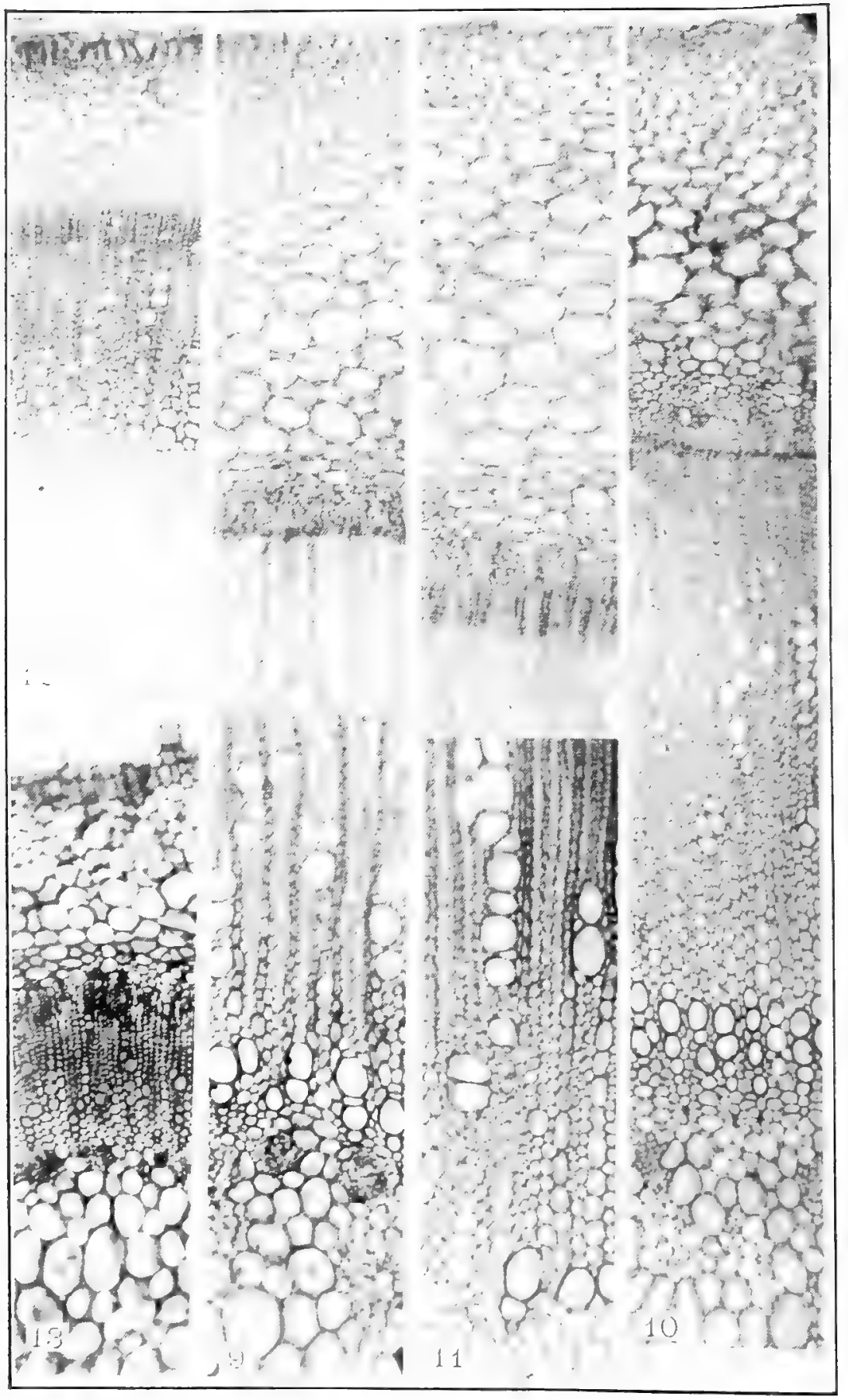




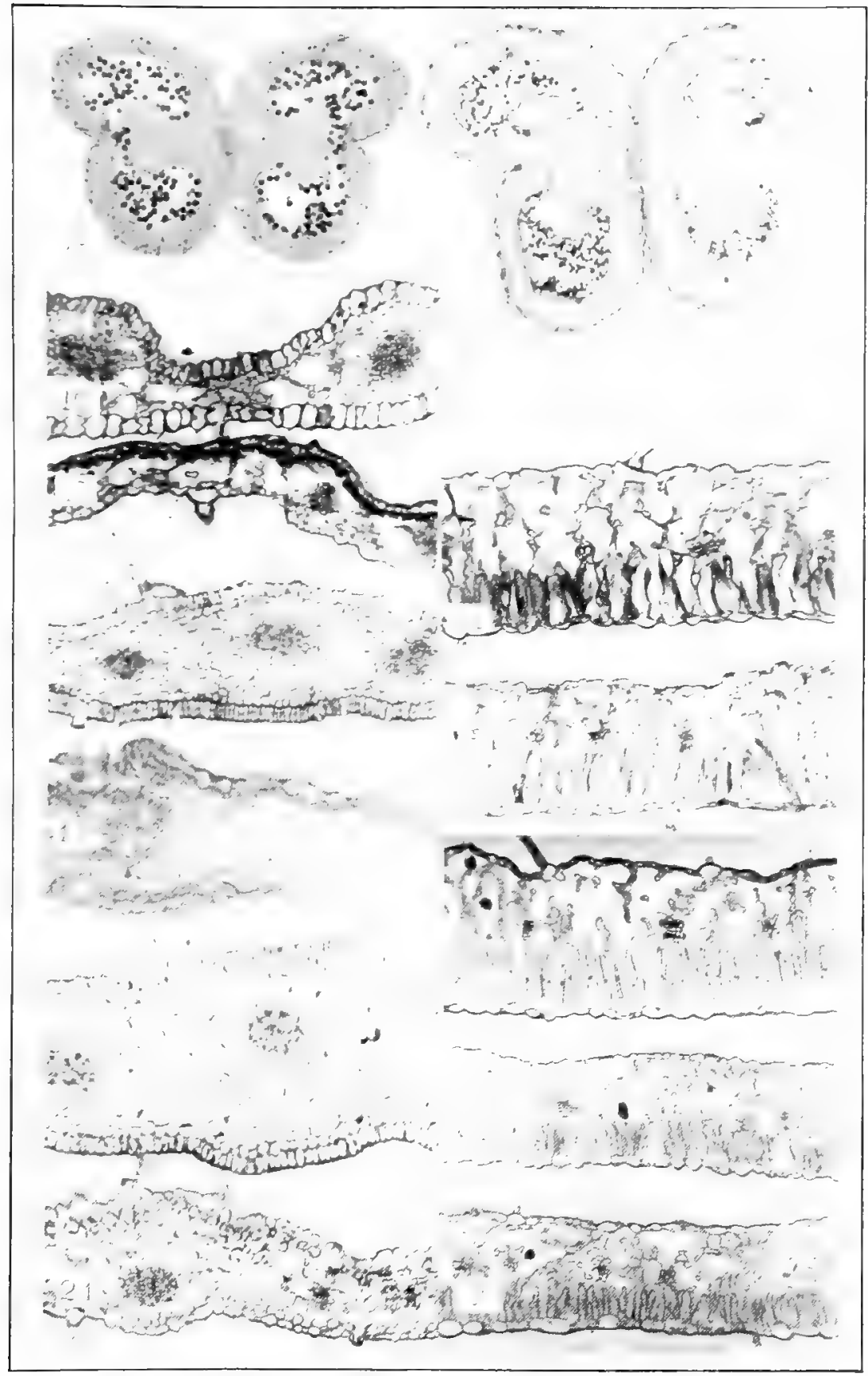




\section{N. Tabacum, N. alata and Hybrid.}

EXTERNAL CHARACTERS TABULATED.

\begin{tabular}{|c|c|c|}
\hline Characters Compared. & N. TABACLM. & HYBRID. \\
\hline Average height, & 11 dc., & $4 \mathrm{dc}$. \\
\hline Shape of leaves, & $\begin{array}{c}\text { Broadly ovate- } \\
\text { lanceolate, }\end{array}$ & $\begin{array}{l}\text { Narrowly lanceolate- } \\
\text { ovate. }\end{array}$ \\
\hline $\begin{array}{l}\text { Average length of } 4 \text { larger } \\
\text { leaves, }\end{array}$ & $60 \mathrm{~cm}$ & $10 \mathrm{~cm}$ \\
\hline $\begin{array}{l}\text { Average width of } 5 \text { larger } \\
\text { leaves, }\end{array}$ & $24 \mathrm{~cm}$. & $2.5 \mathrm{~cm}$ \\
\hline $\begin{array}{l}\text { Thickness of stem, } 30 \mathrm{~cm} \text {. } \\
\text { above ground, }\end{array}$ & $2.5 \mathrm{~cm}$ & $.5 \mathrm{~cm}$ \\
\hline Inflorescence, & Panicle, & Racemose. \\
\hline Length of calyx, & 2. $\mathrm{cm}$., & $2.3 \mathrm{~cm}$ \\
\hline Length of corolla tube, & $4.5 \mathrm{~cm}$. & $6.5 \mathrm{~cm}$ \\
\hline Shape of corolla, & $\begin{array}{l}\text { Somewhat salver- } \\
\text { form, }\end{array}$ & $\begin{array}{l}\text { Somewhat salver- } \\
\text { form. }\end{array}$ \\
\hline Spread of corolla lobes, & $2.5 \mathrm{~cm}$. & $4.2 \mathrm{~cm}$. \\
\hline Color of corolla, & Pink, & Very light pink. \\
\hline Length of anthers, & $.45 \mathrm{~cm}$. & $.35 \mathrm{~cm}$ \\
\hline Color of anthers, & Greenish yellow, & Brownish purple. \\
\hline $\begin{array}{l}\text { Enlargements of stamen fila- } \\
\text { ments at middie, }\end{array}$ & No enlargement, & No enlargement. \\
\hline \multicolumn{3}{|l|}{ Total, } \\
\hline Reduced to per cent., & & \\
\hline
\end{tabular}




\section{N. Tabacum, N. alata and Hybrid.}

EXTERNAL CHARACTERS TABLLATED.

\begin{tabular}{|c|c|c|}
\hline$\therefore$ Alata. & $\because$ ․ TABACUM. & $\because$ I. AldTA. \\
\hline T dc.. & 30.0 & 70.0 \\
\hline Nirrowly lanceolate-ovate, & 0.0 & 100.0 \\
\hline $25 . \mathrm{cm}$. & 23.0 & 77.0 \\
\hline 10. $\mathrm{cm}$ & 25.4 & 74.2 \\
\hline.$\overline{c m}$ & 7.4 & 92.6 \\
\hline Racemose, & 0.0 & 100.0 \\
\hline $3.2 \mathrm{~cm}$. & 7.5 .0 & 25.0 \\
\hline$\therefore \mathrm{cm}$ & 42.8 & .57 .2 \\
\hline Somewhat funnel-form, & 65.0 & 35.0 \\
\hline $5.5 \mathrm{~cm}$. & 43.3 & 56.7 \\
\hline White, & 40.0 & 60.0 \\
\hline $.5 \mathrm{~cm}$ & 60.0 & 40.0 \\
\hline Brownish-purple, & 0.0 & 100.0 \\
\hline \multirow[t]{3}{*}{ Enlarged, } & 100.0 & 0.0 \\
\hline & +12.3 & $8 \times 7.7$ \\
\hline & 36.5 , & 63.5 \\
\hline
\end{tabular}




\section{Nicotiana Tabacum, N. alata and Hybrid.}

HISTOLOGICAL CHARACTERS TAFULATER.

\begin{tabular}{|c|c|c|}
\hline Characters Compared. & N. TABACLM. & N. TABACLM X N. Alata. \\
\hline Thickness of cortex, & $1055 \mu$ & $.52 .5 \mu$ \\
\hline Thickness of xylem, & $2000 \mu$ & $300 \mu$ \\
\hline Tol. of epidermal cells, & 167,400 си $\mu$. & 35,568 сuн. \\
\hline Hypodermal cells of stem, & Like cortical cells, & $\begin{array}{c}\text { Somewhat like leaf } \\
\text { mesophyll. }\end{array}$ \\
\hline Diameter of bast fibers, & $42 \mu$ & $44 \mu$ \\
\hline Thickness of wall of bast fibers, & $10 \mu$ & $3.75 \mu$ \\
\hline Diameter of xylem vessels, & $65 \mu$ & $35 \mu$ \\
\hline Diam. of tracheid cells of stem, & $20 \mu$ & $22 \mu$ \\
\hline Diam. of pith cells of stem, & $190 \mu$ & $125 \mu$ \\
\hline $\begin{array}{l}\text { Diam. of nuclei of pith celis } \\
\text { of stem, }\end{array}$ & $22 \mu$ & $10 \mu$ \\
\hline Medullary rays of stem, & Well differentiated, & Not well differentiated. \\
\hline Thickness of anthers, & $2220 \mu$ & $2025 \mu$ \\
\hline Shape of anthers, & & Intermediate. \\
\hline Cells in wall of loculus, & $\begin{array}{c}2 \text { rows of rather } \\
\text { large cells, }\end{array}$ & $\begin{array}{l}2 \text { rows of rather large } \\
\text { cells. }\end{array}$ \\
\hline Size of pollen grains, & $24 \mu$ & $27.5 \mu$ \\
\hline Thickness of corolla, & $412 \mu$ & $210 \mu$ \\
\hline Thickness of calyx, & $225 \mu$ & $2.50 \mu$ \\
\hline $\begin{array}{l}\text { Sub-epidermal layer in inside } \\
\text { of calyx, }\end{array}$ & Cells thin-walled, & Cells thick-walled. \\
\hline \multicolumn{3}{|l|}{ Total, } \\
\hline Reduced to per cent., & & \\
\hline
\end{tabular}


Nicotiana Tabacum, N. alata and Hybrid. HISTOLOGICAL CHARACTERS TABLLATED.

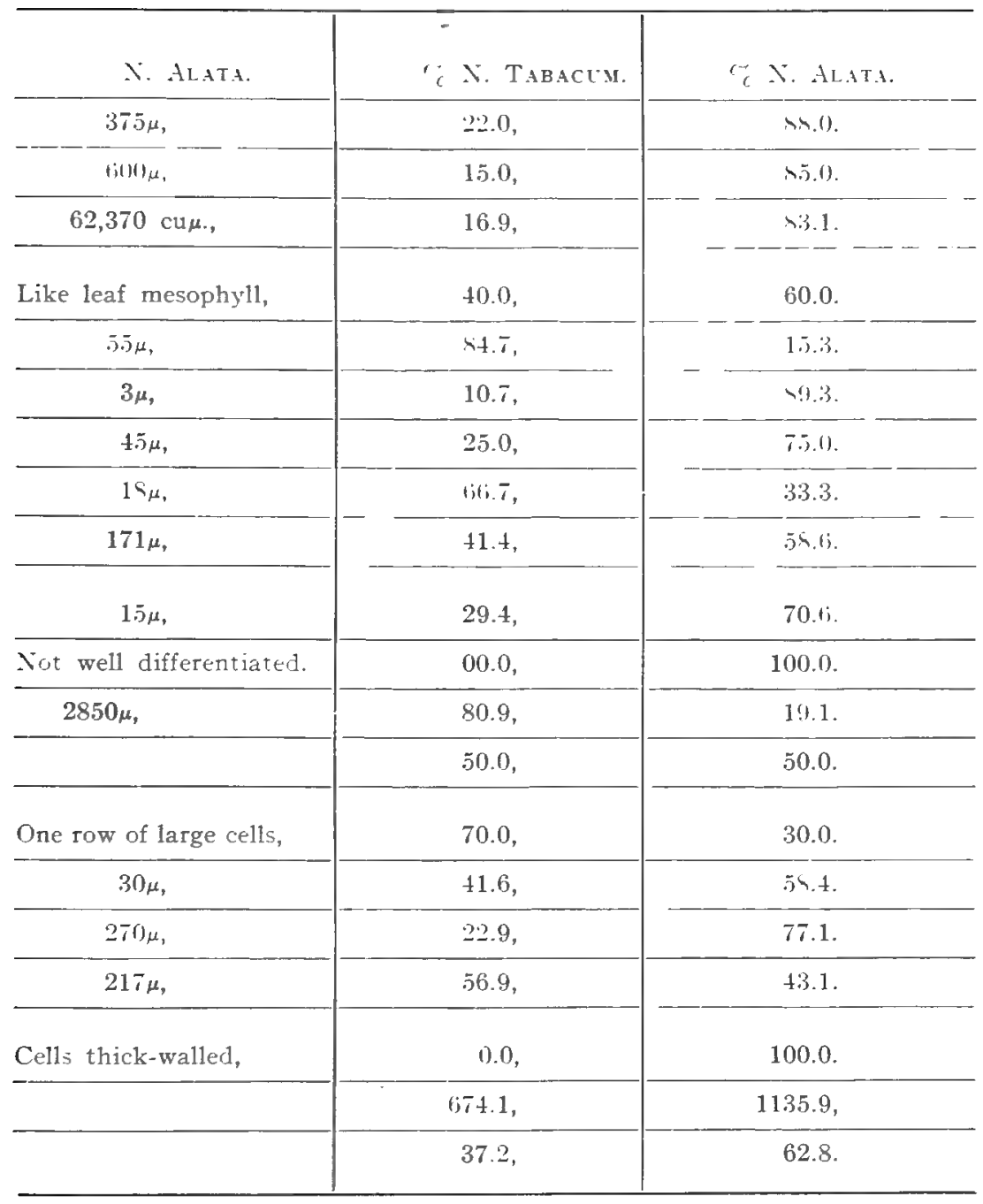




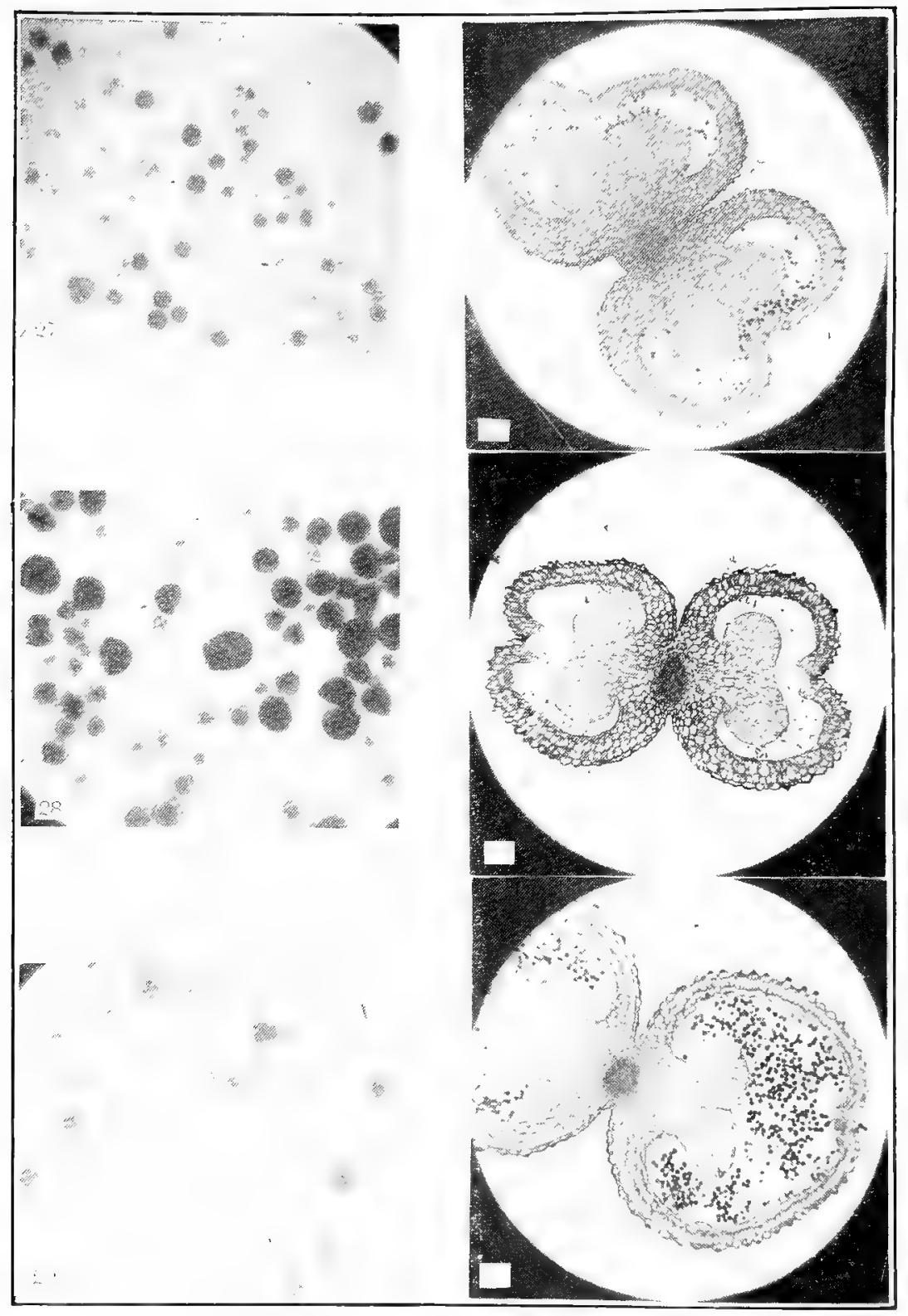

Fig. 30.-Cross section N. Tabacum anther.

Fig. 31.-Cross section N. Tabacum $\times$ N. alata anther.

Fig. 32.-Cross section $N$. alata anther. 
From the discussion and tables, it will be seen that the $\mathrm{N}$. Tallacum $x \mathrm{~N}$. alata hybrid inherited $36.5 \%$ o its cxternal characters, and $37.2 \%$ of its internal or microscopic structural characters from $\mathrm{N}$. Tal a acum, the pistillate parent, while $63.5 \%$ of its external and $62.8 \%$ of its internal characters were inherited from $\mathrm{N}$. alata, the staminate parent. In this hybrid, as in the $\mathrm{N}$. Tabacum $x \mathrm{~N}$. strestris cross, there seems to be a close relationship between internal and extermal characters; a parent don inant in one is also dominant in the other by about the same per cent.

In this cross, the pistillate parent had pure dominance in none of the internal characters and in only one of the external; the staminate parent had complete dominance in three external and two internal characters. Here, as in the first cross liscussed, the majority of the characters, both internal and external, were internediate, -ten of the fourteen external characters compared, and sixteen of the eighteen internal.

In the plants studied there seems to be no uniformity in the influence of either parent over individual characters; for instance, in the $N$.

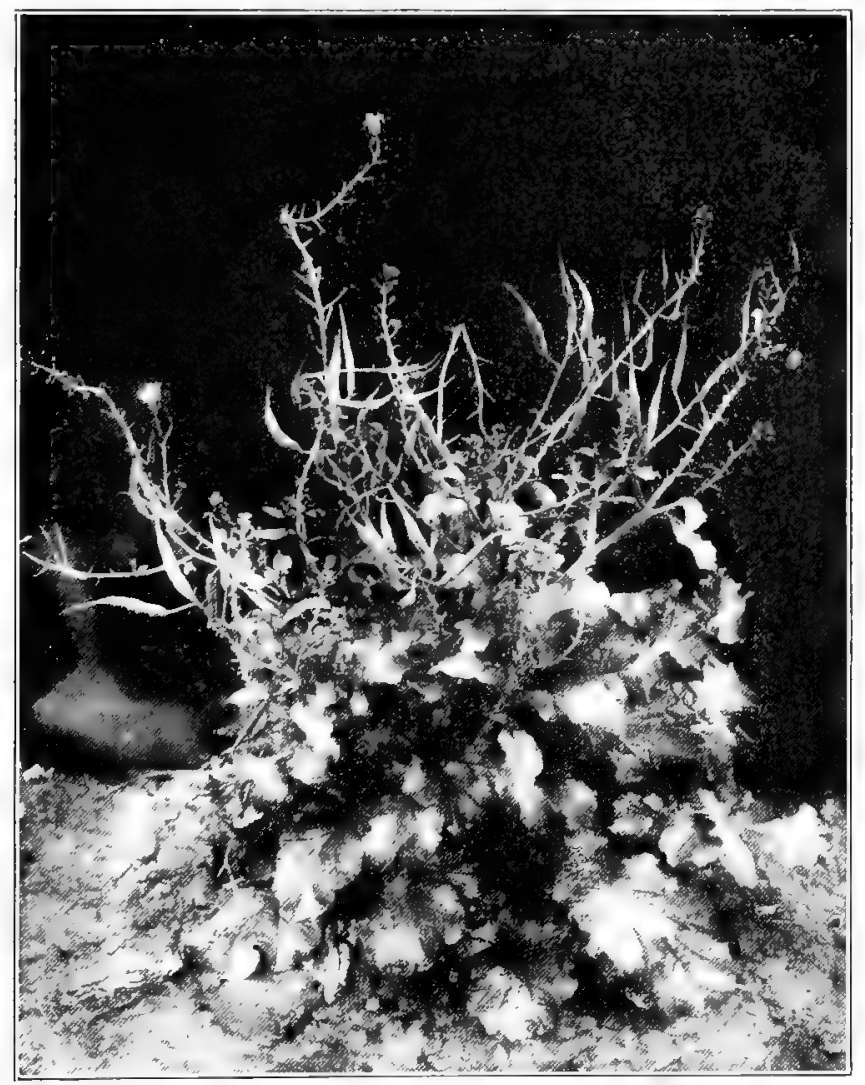

Fig. 33.-Radish. 
Tabacum $x \mathrm{~N}$. sylvestris hybrid the pistillate parent, N. Tabacum, was dominant over the shape of the leaves, while in the N. Tabacum $x \mathrm{~N}$. alata hybrid, the staminate parent, N. alata, was dominant over the same character. In the case of the majority of the characters of these two hybrids, one parent was dominant in one cross, and the other parent dominant over the same characters in the other cross.

In most of the tissue of the N. Tabacum $x \mathrm{~N}$. alata bybrid, the cells are ccnsiderably smaller than corresponding cells of either parent. This, in part at least, accounts for the dwarfness of the hybrid.

\section{Brassica oleracea, var. caulo-rapa, Raphanus sativus and Hybrid.}

The Raphanus sativus used as a pistillate parent in the Raphanus sativus x Brassica oleracea, var. caulo-rapa cross is a common radish of vegetable gardens, - a variety with a large, white conical root. The seeds of this plant germinate soon after planting and a large flowering plant is produced in a few weeks. Figure 33 shows one of the plants after it has been flowering for a short time. After beginning, the plant continues to blossom throughout the remainder of the scason.

The Brassica oleracea, var. caulo-rapa used as a staminate parent in the above cross, is a common purple variety of Kohlrabi of vegetable gardens. Seed gathered from the staminate parent of the hybrid were planted the first of June. They germinated at once, but the plants grew rather slowly. No flowering stalks had started to form by the first of October, when the plants were brought into the green-house. In the green-house the plants grew slowly, and began to send out flowering stems about the first of January; flower buds were first noticed February 8 . Figure 34 shows a plant soon after beginning to blossom. (Further details of description of both kohlrabi and radish plants are given in the tables and under the discussion of the hybrid.)

The seeds produced by crossing radish and kohlrabi were planted about May 15, 1909. They germinated at once, and produced two seedling plants which at first resembled the radish parent considerably, except in color; they had the purplish blue color of the male parent, kohlrabi, the color not being so deep, however.

One of the seedlings grew much more rapidly than the other, but the two had the same general appearance at different stages. On August 1 , the larger one of the two was $30 \mathrm{c}$. high, and had a spread of leaves of about $70 \mathrm{~cm}$. The leaves were at first ascending, but later became spreading. At that time, the stem at the point of insertion of the large leaves had enlarged considerably, forming a sort of globular thickening about $4 \mathrm{~cm}$. in diameter. The root, at this stage, had also thickened considerably.

On August 16, the first flower buds were noticed. About this time, the upper part of the stem began to branch, and lengthen rapidly, forming long, slender branches, bearing flower buds (fig. 35). The first buds that formed, dropped off before reaching full size; later ones developed farther and farther until some nearly perfect flowers appeared, flowers with sepals, full size spreading petals, six stamens and a well formed pistil (fig. 41c.). However, the majority of the flowers failed to open and had small and imperfectly developed parts. No good 


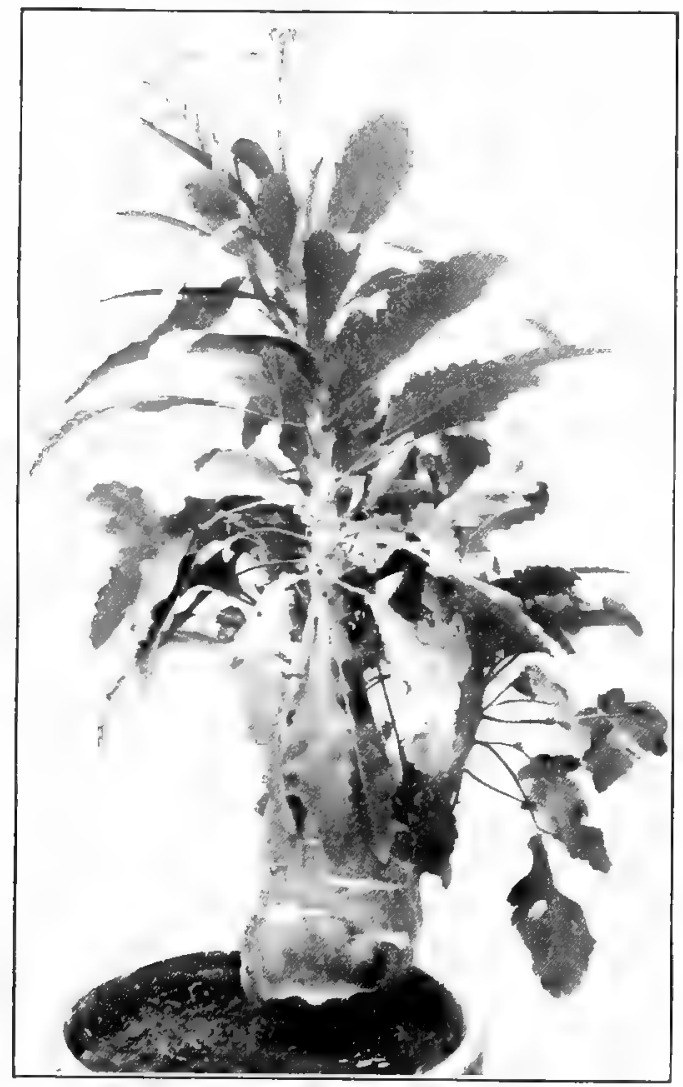

Fig. 34.-Kohlrabi.

prollen was yr ducerl and comseguently no seorl set. The plants were brought into the ureen-house abrut Getolee 1 . The following alescription applices to, the appearance of the plants at that time

Radish $\mathrm{x}$ kohlrati hybrid, heisht at maturity 72 (m., ylalorous, leaves numere us, irster sircarling, $30-38 \mathrm{~cm}$. 1ong, $10-13 \mathrm{~cm}$. write; irregularly pinzate, $12-17$ pinnese, ond vinna large and irregulaty orbicular (fig. 40c.). The leaves are smaller above, the upuermost being small, lincar and nearly enfirc; colrs, a purplish hluc-grecn, mid-

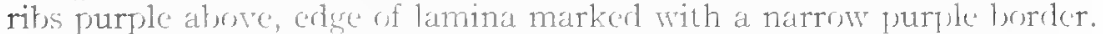
The stem is enlared consilerably just abore the root, forming a fusiform thickening, about $6.5 \mathrm{~cm}$. in diameter and $15 \mathrm{~cm}$. 1ong; this tapers upward, giving rise to an irregular, tapering main axis and screral branches (fig. 36). Táp root is conical, $4 \mathrm{~cm}$. in diameter at tris) and about $20 \mathrm{~cm}$. long, with rather numerous scendary roots (fig. 36). Numerous, young plants sprouter out from the roots. Flower buds are numerous, but few fully developed flowers. The most perfect ones have four sepals, thickish, hoat-shaped, linear oblong, obtuse, $8-9 \mathrm{~mm}$. 
long, 2 - $3 \mathrm{~mm}$. wide, green; petals 4, wedge-shaped, rounded at apex, 9 - $11 \mathrm{~mm}$. long, and $3.5 \mathrm{~mm}$. wide; lamina pale yellow with purple veins and a purplish margin; stamens $4,4 \mathrm{~mm}$. long, anthers $2 \mathrm{~mm}$. long; anthers soften as they approach maturity, producing no good pollen. Stigma small, capitate, yellow; style thickish, cylindrical to. fusiform, $4 \mathrm{~mm}$. long, $1 \mathrm{~mm}$. thick; ovary cylindrical, $5 \mathrm{~mm}$. long, $1 \mathrm{~mm}$. thick. No fruit matured.

The radish $\mathrm{x}$ kohlrabi hybrid shows several interesting characters. when compared with its parents. The color of the entire plant is much like that of the staminate parent, although not quite such a deep purple; the color of the flowers is intermediate, having some of the yellow of the kohlrabi parent and the purple veins of the radish parent.

The hybrid is entirely glabrous, like the staminate parent. Its leaves are like those of the radish parent in form and shape, being slightly shorter and more narrow; they have about the same "feel" and

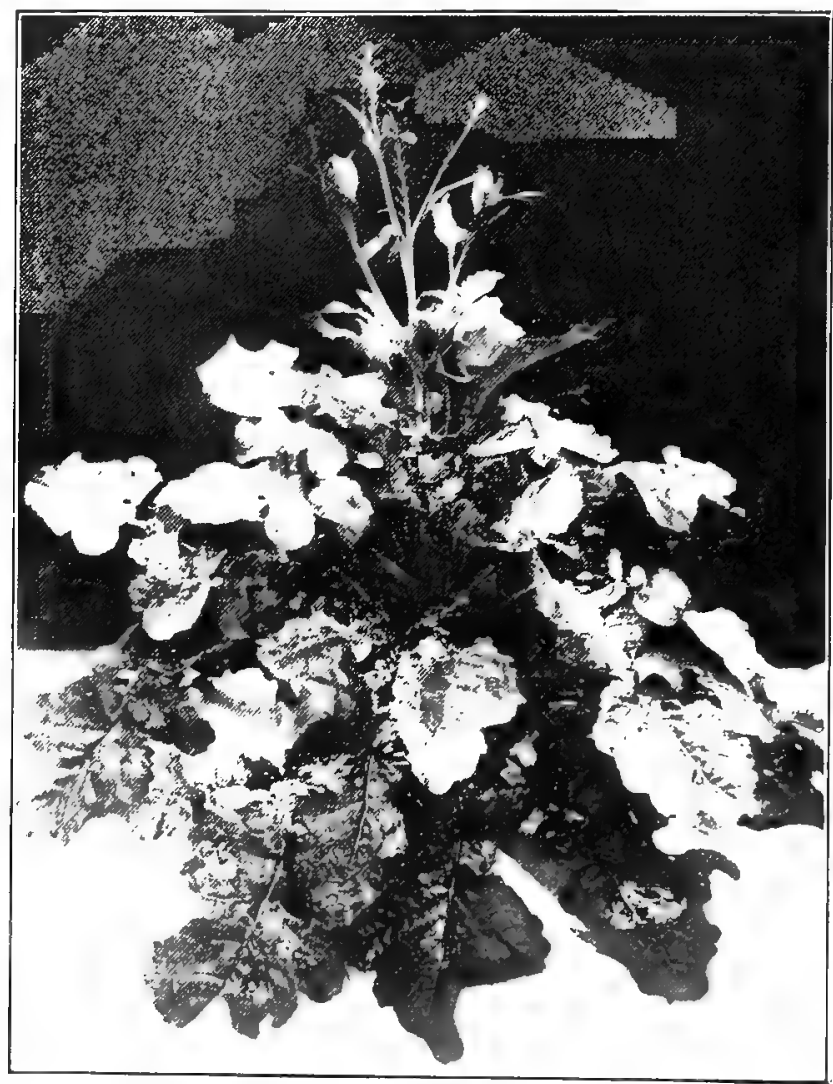

Fig. 35.-Radish

Kohlrabl 
texture as kohlrabi leaves; they, like the leaves of kohlrabi, when bent, tend to remain so (like a bar of lead); that is, they seem to lack power of springing back into normal shape.

The thickening of the stem is not so large as in kohlrabi, but, except being nearer the ground, is much like it. The radish stem has no thickening of this sort. The root is about the same size and shape as the radish root, but is much more branched. It contains a thicker cortex and a woody central part. The root of kohlrabi is small, woody and much branched. No young plants have been seen rising from the roots of either parent.

Cabbage worms ate the hrbrid greedily, it being a task to keep them off; they ate kohlrabi to some extent, but did not eat the radish at all. The hybrid had a taste somewhat different from that of either parent, a decided turnip taste in addition to the pungent taste of the radish parent.

\section{Raphanus sativus, Bassica oleracea, var. caulo-rapa and Hybrid.}

\section{HISTOLOGICAL CHARACTERS.}

Stem Structure: The Radish stem, as was stated above, has no enlargement corresponding to the stem thickening of Kohlrabi and the hybrid. The stem in this part of the plant is from 1.5 to $2 \mathrm{~cm}$. thick. A cross-section shows a fairly well defined cortex, within which is a woody ring $3-4 \mathrm{~mm}$. in thickness, and in the center, there is a mass of spongy pith (fig. 38 b.). A cross-section of the corresponding part of Kohlrabi, shows a comparatively narrow but well defined cortex within which is a ring of small, irregular, scattered vascular bundles, while the central part, forming the main mass of the structure, consists of more or less succulent parenchyma tissue in which there are a few small, scattered vascular bundles (fig. 37 b.). The hybrid stem at this print has a rather thick cortex, which varies in thickness in different places; within this is a woody ring, consisting of wide, flat plates of Xylem of varying widths, and rather loosely joined. The central part of the structure is here also made up of rather succulent parenchyma tissue, being similar to the tissue of the corresponding part of Kohlrabi, but even more dense.

Taking up stem structure in more detail, we notice that each of the three plants under comparison has a well defined epidermis, the cells being flattened somewhat. In Radish they are $21-24 \mu$ thick, and $33-68 \mu$ long; in Kohlrabi, $15 \mu$ thick, and $15-45 \mu$ long; and in the hybrid, $15-21_{\mu}$ thick, and $20-30 \mu$ long. Over certain parts of the hybrid stem, the epidermis has disappeared, and these parts are covered by a. periderm consisting of several layers of cells which are more or less suberized.

The cortical cells of the three plants are similar in form and texture. In Radish and the hybrid, they gradually shade off into the ground tissue of the central part of the stem, but in Kohlrabi the cortex is limited inward by a more or less well defined cambium.

The prominent woody ring of the Radish stem is made up of xylem strands that fit together rather closely. These strands are grouped in a peculiar manner, 3 to 5 or 6 run together toward the pith and in the form 


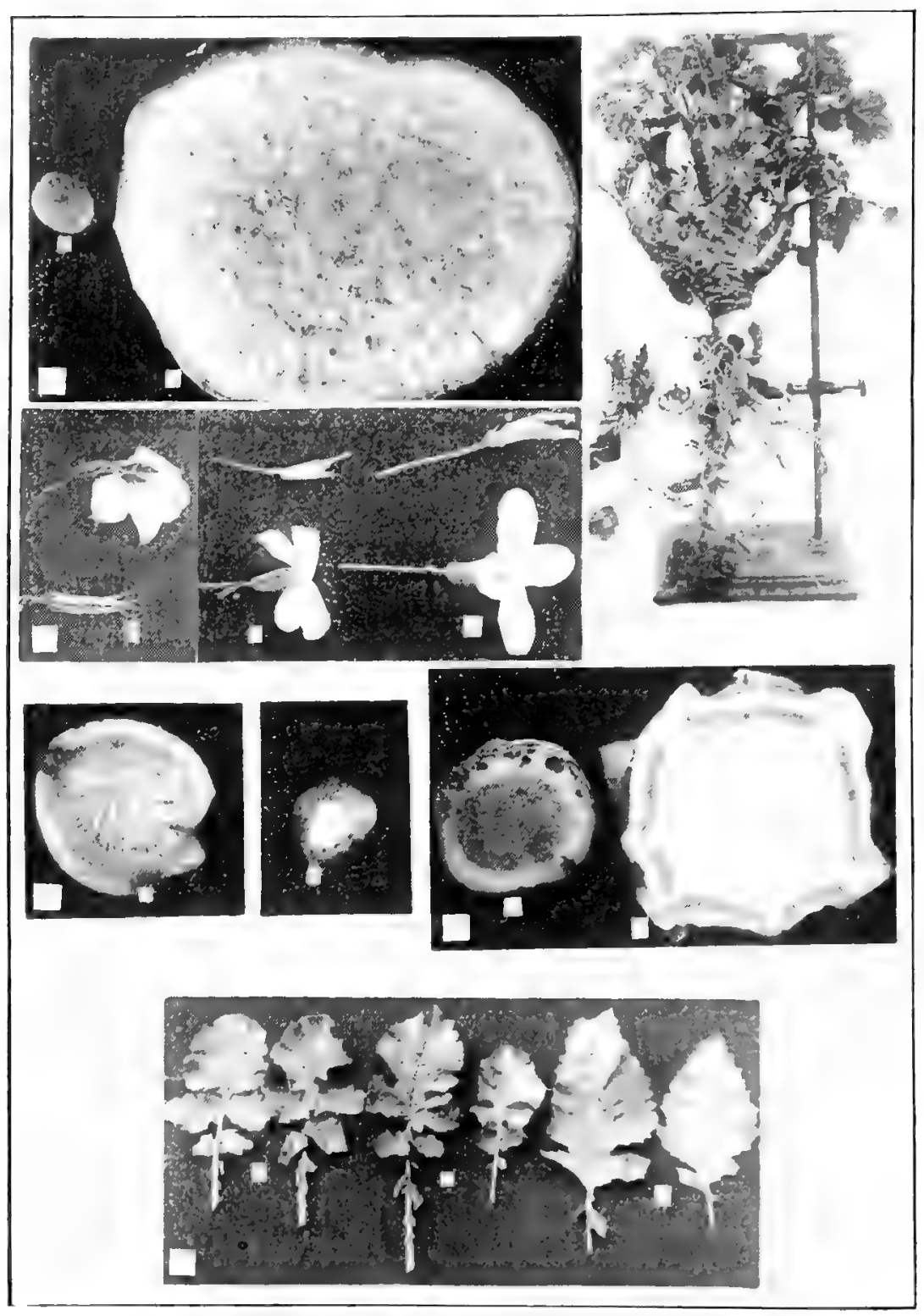


of a wedge, project into it, for a greater or less distance (fig. 48). The individual bundles in this aggregation are very wide radially, but narrow in the direction of the stem circumference. They are separated by about three rows of elongated, thin-walled parenchyma cells which resemble medullary rays. The groups of bundles are separated by similar rows of cells, usually about five. The groups vary considerably in size and their limits are not well marked out in some cases.

In Kohlrabi, the woody ring of the stem is very rudimentary; this is formed of small, irregular, scattered xylem strands; these are widely separated by parenchyma cells (fig. 49). In the hybrid, the xylem strands are varied; some are small and irregular, as in Kohlrabi, while others are much larger, the majority being several hundred microns in length (in the direction of the stem radius). (Fig. 50.) The larger strands are grouped much as in the Radish stem.

The phloem strands in the Radish stem are prominent, and well defined. Each possesses sieve tubes $18-25 \mu$ in diameter, and companion cells $3-5 \mu$. Peripheral to each phloem strand, is a strand of sclerenchyma tissue which appears crescent-shaped in cross section. In the Kohlrabi stem, the phloem is scarcely distinguishable, appearing merely as a few smaller, more deeply staining cells standing peripherally to the xylem strands. In the hybrid there are prominent long, narrow phloem strands.

The xylem of the stem bundles of each of the three plants contains scattered pitted vessels $25-75 \mu$ in diameter and tracheids $10-30 \mu$ in diameter. The difference in the xylem strands of the three plants lies in the number of cells that enter into their structure rather than in the form of the individual cells.

The pith or ground tissue cells in the central part of the stem are sub-spherical in each of the three plants and about the same size. The walls are cellulose, thin, being apparently somewhat thinner in the Radish stem than in the other two. They contain numerous large pits, or thin places.

RoOT StRUCTLRE: (A cross section of the largest part of the root of each of the plants under comparison was used.) Radish root has a cortex $3650 \mu$ thick, Kohlrabi $1800 \mu$, and the hybrid $5000-7000 \mu$.

Within the primary cortex of the Radish root there is a ring of well defined vascular bundles, but their xylem elements are lignified only slightly; the rest of the root tissue is made up of parenchyma cells. All of the tissue within the cambium of the root of the hybrid appears to be woody, when viewed macroscopically, but a closer inspection shows that it contains tissues other than the woody. All of the root of the Kohlrabi, except the part without the cambium, is made up of dense wood.

Taking up the structure of the roots in detail, we find that in each plant the epidermis has disappeared, the outer part of the root being covered by a periderm several layers of cells thick. The ground tissue cells of the cortex, in each plant, are thin-walled and sub-globular, with a tendency to elongation in the direction of the circumference of the root. In Radish, these cells average about $150 \mu$ in length, in Kohlrabi $50 \mu$, and in the hybrid $60 \mu$. The cortex of Kohlrabi contains 
numerous small clusters of fibrous cells with thickened lignified walls. These resemble ordinary bast fibres except that the lumen is comparatively wide and the cells large, being about $39 \mu$ in diameter, with a wall about $5 \mu$ in thickness. In the hybrid cortex, there are similar clusters of fibrous cells; here they are slightly larger, averaging $50 \mu$ in diameter, with a wall thickness about $5 \mu$. The clusters are not so abundant, nor are there as many fibers in a cluster, not being more than half as many fibers altogether. In the cortex of the Radish root, these fibers are entirely lacking. In each of the three plants, the ground tissue cells of the cortex become shorter inward and gradually pass over into medullary rays separating the vascular bundles. Between the bundles, they are elongated in the direction of the root radius. In Radish, there are 2 - 12 rows of cells in each ray; the cells being $15-75 \mu$ long, and $15-30 \mu$ wide. In Kohlrabi, there are $3-4$ rows of cells in a ray, the cells being $15 \mu$ wide and $25-30 \mu$ long; in the hybrid, there are $4-8$ rows of cells in a ray, the cells being $24-30 \mu$ wide, and $40-60 \mu$ long (figs. 45, 46, and 47). In Radish, and in the hybrid, the rays widen toward the pith, the cells gradually passing over into the large, globular, thin-walled pith cells. Pith cells are lacking altogether in the root of Kohlrabi.

The phloem areas are rather prominent in each of the three plants, being most prominent in the hybrid. In each, they gradually shade off into the ground parenchyma so it is difficult to point out their exact limits. plants.

The cambium was not sharply differentiated in any of the three

Cross-sections of Radish roots show xylem strands of varying length and width; they average about $3300 \mu$ long and $225 \mu$ wide; in Kohlrabi they average about $200 \mu$ in width and are $6200 \mu$ in length, extending from the cortex to the center of the root; in the hybrid they are of varying widths, ranging from $150-550 \mu$ and are about $12,000 \mu$ long. The xylem strands in each of the three plants are made up of pitted vessels and tracheids, their walls being more or less lignified. The vessels and tracheids are about the same size in the three plants, being slightly larger in Radish than in the other two; the walls of the tracheid cells in Kohlrabi are about $2.5 \mu$ thick, and strongly lignified, while the walls of Radish are about $1 \mu$ thick, and but slightly lignified; in the hybrid the tracheid walls are about $2 \mu$ in diameter and not strongly lignified.

Structure of Mid-rib of Leaf: (Studies from cross sections taken near the base of the leaf-blade.) The mid-ribs of the leaves of the three plants have much the same shape and size, and in general, the structure is similar. The mid-rib of Kohlrabi is slightly smaller than the mid-ribs of the other two, being about $4000 \mu$ in diameter, while in Radish the diameter is about $5500 \mu$, and in the hybrid about $5000 \mu$. There is about the same number of vascular bundles in each and their distribution is similar in general. In Kohlrabi, the bundles are rather large and compound, each large bundle being composed of 2 to 5 small ones joined more or less; the Radish bundles are not compound as in Kollrabi, or, if compound, the members are so closely united that they apfear as one; these bundles are of rather uniform size, and are con- 
siderably smaller than the compound Kohlrabi bundles. In the hybrid, the bundles are intermediate in size and shape, being slightly nearer the Radish bundle in size, and the Kohlrabi bundle in shape.

Taking up the structure of the petiole in more detail we notice that the epidermal cells have a thick cutinized outer wall about $6-9_{\mu}$ thick in each of the three plants. Just under the epidermal cells in the Radish petiole there are 1-6 layers of collenchyma cells, there being only one layer most of the way around; in Kohlrabi there are 2 - 11 layers of these cells, 2 - 3 most of the way around, except at the angles, where there are more; in the hybrid there is but one well defined layer most of the way around. The greater part of the mid-rib in each plant is made up of sub-spherical, thin-walled parenchyma cells; in Radish these cells are $150-200 \mu$ in diameter, diminishing somewhat in size toward the periphery; in Kohlrabi they average about $75 \mu$ in diameter; in the hybrid they average $135 \mu$ in diameter, and become slightly smaller toward the periphery.

As was stated above, the large vascular bundles in the mid-rib of Radish, or the compound bundles in Kohlrabi and the hybrid appear crescent-shaped in cross-section. In the central part of the mass of tissue within the horns of the crescent is a mass of sclerenchyma tissue which is made up of cells $12-21_{\mu}$ in diameter, with walls thickened uniformly and strongly lignified. The corresponding cells in Kohlrabi are parenchymatous with a slight indication of the beginning of the formation of collenchyma tissue; in the hybrid, well developed collenchyma tissue fills this space. In Kohlrabi and in the hybrid, rays of these cells extend out between the parts of the compound bundle, thus simulating medullary rays. The xylem in each plant consists of numerous annualar and spiral vessels and xylem parenchyma cells; and in the Radish, the vessels average $33 \mu$ in diameter; in Kohlrabi they are some larger, being about $45 \mu$ in diameter, while in the hybrid they are about $36 \mu$ wide. Fascicular cambium is well developed in the bundles of each; it consists of several layers of brick-shaped cells, each being about $5 \mu$ wide and $15 \mu$ long. Sieve tubes and companion cells are prominent in the phloem of each plant, and are of about the same size in each. In Radish, there is a layer of sclerenchyma tissue $100 \mu$ wide, bounding the phloem on the outer side; this is made up of cells similar to the sclerenchyma cells in the central part of the bundle. Kohlrabi and the hybrid have, corresponding to this tissue, strands of collen. chyma tissue peripheral to each part of the compound vascular bundle .

Leaf Lamina Structure: The entire thickness of the Radish leaf lamina is $330 \mu$ (sections taken in the central part of the leaf blade at one side of the mid-rib); Kohlrabi leaf has a thickness of $300 z$ and the hybrid leaf $360 \mu$. The lower epidermal cells of Radish leaf are about $15 \mu$ thick (in direction perpendicular to leaf surface), and have a rather thin outer wall, it being less than $2 \mu$ in thickness; the upper epidermal cells have about the same thickness with a slightly thicker outer wall, it being $2-3 \mu$ in thickness. On either side of the leaves of Kohlrabi, the epidermal cells are $21-25 \mu$ thick, and have an outer wall $3 \mu$ thick. In the hybrid, the epidermal cells average about $22 \mu$ in thickness, and have an outer wall thickness of $3-6 \mu$. 
The leaf mesophyll is rather dense in each of the three plants under comparison, being made up of spongy parenchyma and palisade cells in about equal amounts (figs. 51, 52 and 53). There are 2 to 4 layers of the palisade cells, being $2-3$ in Radish and 3-4 in the other two plants. In Radish, these cells are about $45 \mu$ in length, while in Kohlrabi, they are $33 \mu$ long and in the hybrid about $40 \mu$.

Surface sections of the leaves show stomates on each side. there being a few more on the under side than on the upper. On either side, the stomates seem to be rather uniformly distributed. The guard cells are about the same size in each of the three plants. Mounts made from the Radish leaf show about 40 stomates, on the average, in the microscopic field ( 1 inch ocular and 1-6 inch objective), when mounts are made from the under side of the leaf and 30 when from the upper; Kohlrabi shows 28 and 22 respectively and the hybrid 38 and 30 , the average numbers of the three for both surfaces being 35,24 , and 34 .

The regular epidermal cells from the under side of the leaves seem to differ considerably in the three plants, when viewed in surface view. In Radish, they have a wavy, sintuo.s outline (fig. 44), and average about $75 \mu$ in length; in Kohlrabi, they are more or less irregularly rectangular, without a wavy outline, and average about $45 \mu$ in length (fig. 42); in the hybrid they have about the same shape as in Kohlrabi, but they are considerably longer, being about $70_{\mu}$ in length, nearly as long as the corresponding cells in Radish (fig. 43).

A comparative study of the microscopical structure of the flowers of the three plants has not been made. However, ovaries and young anthers of the hybrid were sectioned. The ovaries and young ovules seemed to be perfectly normal in the sections examined, but further study and experiment is needed to determine whether or not they would form seed, providing the pollen element was normal. Sections of the young anthers showed pollen mother cells beginning to disintegrate or break down while in the resting stage. 

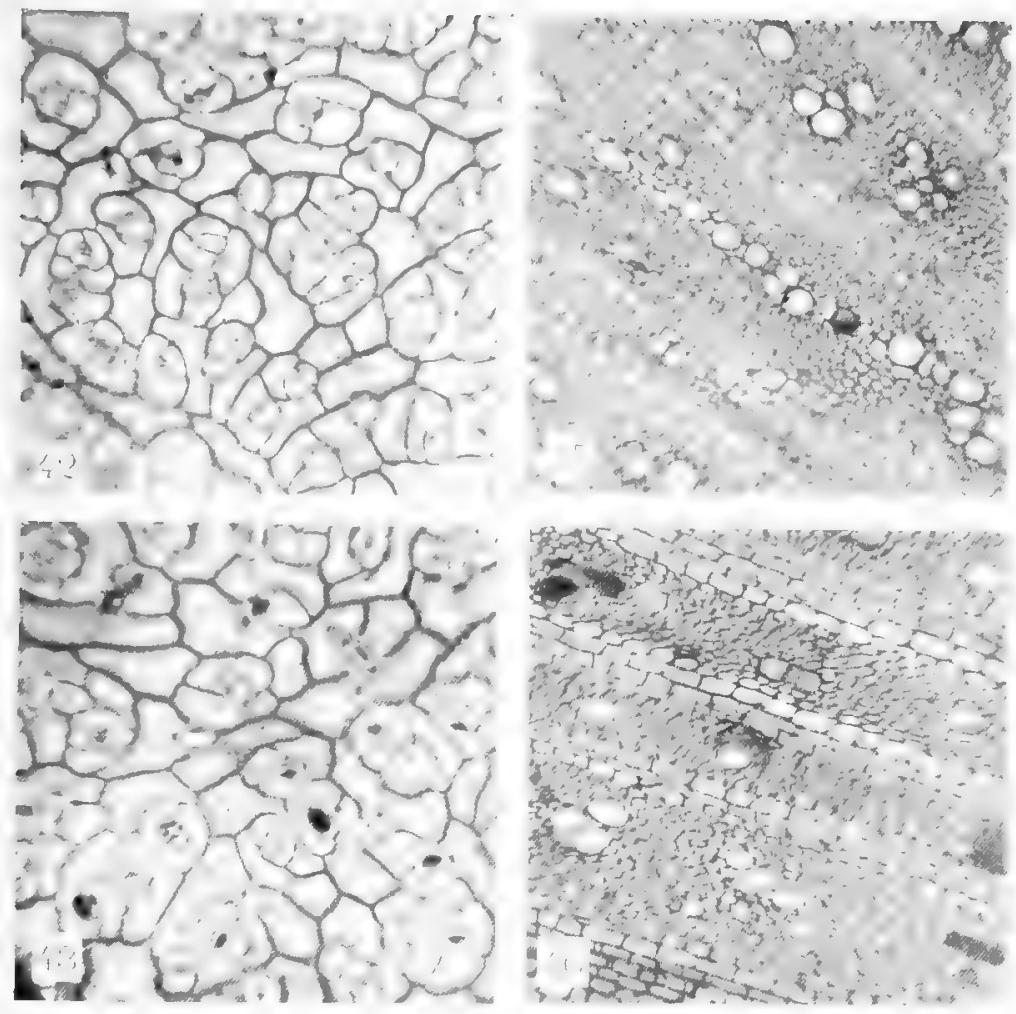

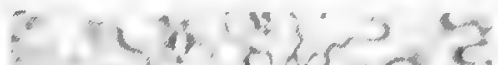

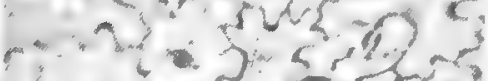

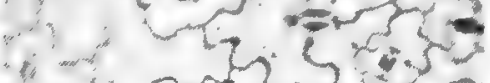

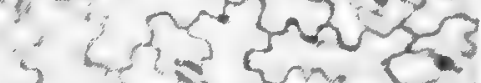
$\rightarrow m 5 n$

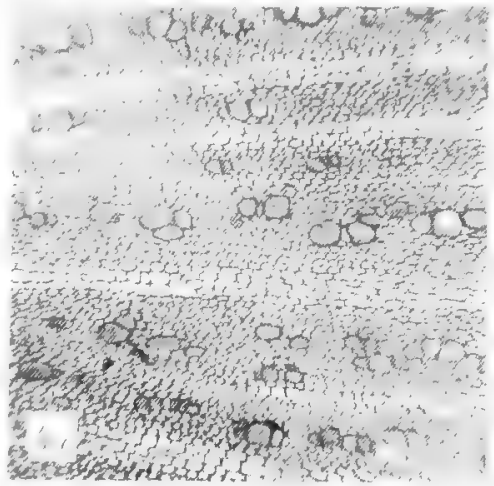




\section{Radish, Kohlrabi, and Hybrid.}

EXTERNAL CHARACTERS TABULATED.

\begin{tabular}{|c|c|c|}
\hline Characters. & RADISH. & HYBRID. \\
\hline Height at maturity, & $70 \mathrm{~cm}$ & $72 \mathrm{~cm}$ \\
\hline $\begin{array}{l}\text { Hat it of learves on young } \\
\text { plant, }\end{array}$ & Ascending, & Ascending to spreading. \\
\hline Composition of leaves, & Pinnately divided, & Pinnately divided. \\
\hline Form of leaves, & $\begin{array}{c}\text { Oblanceolate to } \\
\text { obovate, }\end{array}$ & Oblanceolate to obovate. \\
\hline Tip of leaves, & Rounded, & Rounded. \\
\hline Texture of leaves, & Stiff and brittle, & Pliable and tough. \\
\hline Collor of plant, & Green, & Light purple klue-green. \\
\hline Pubescence, & Somewhat pubescent, & Glabrous. \\
\hline Diam. of stem at largest part, & $2 \mathrm{~cm}$. & 6. $5 \mathrm{~cm}$. \\
\hline Diam. of root at largest part, & $4 \mathrm{~cm}$ & $4 \mathrm{~cm}$. \\
\hline Shape of root, & Conical, & Conical. \\
\hline Root branches, & Few and small, & $\begin{array}{c}\text { Rather numerous and } \\
\text { medium large. }\end{array}$ \\
\hline Color of petals, & White, purple-veined, & $\begin{array}{l}\text { Pale yellow, purple- } \\
\text { veined. }\end{array}$ \\
\hline Length of anther, & $2.5 \mathrm{~mm}$. & $2 \mathrm{~mm}$. \\
\hline Length of filament, & $10 \mathrm{~mm}$. & $2 \mathrm{~mm}$. \\
\hline \multicolumn{3}{|l|}{ Total, } \\
\hline Reduced to per cent., & & \\
\hline
\end{tabular}




\section{Radish, Kohlrabi and Hybrid.}

EXTERNAL CHARACTERS TABULATED.

\begin{tabular}{|c|c|c|}
\hline Kohlrabi. & " RADIsH. & $\%$ Kohlrabi. \\
\hline $100 \mathrm{~cm}$. & 93.4 & 6.6 \\
\hline Spreading, & 60.0 & 40.0 \\
\hline $\begin{array}{l}\text { Pinnately divided only at } \\
\text { base, }\end{array}$ & 90.0 & 10.0 \\
\hline Obovate, & 100.0 & 0.0 \\
\hline Acute, & 100.0 & 0.0 \\
\hline Pliatle and tough, & 10.0 & 90.0 \\
\hline Purplish green, & 30.0 & 70.0 \\
\hline Glabrous, & 0.0 & 100.0 \\
\hline $11 \mathrm{~cm}$. & 50.0 & 50.0 \\
\hline $1.6 \mathrm{~cm}$. & 100.0 & 0.0 \\
\hline Cylindrical, & 100.0 & 0.0 \\
\hline Numerous, fibrous, & 20.0 & 80.0 \\
\hline Rich yellow, & 60.0 & 40.0 \\
\hline $5 \mathrm{~mm}$ & 85.8 & 14.2. \\
\hline \multirow[t]{3}{*}{$6 \mathrm{~mm}}$. & 33.3 & 66.7. \\
\hline & 932.5 & 567.5 \\
\hline & 62.2 & 37.8 \\
\hline
\end{tabular}




\section{Radish, Koh rabi, and Hybrid.}

HISTOLOGICAL CHARACTERS TABULATED.

\begin{tabular}{|c|c|c|}
\hline CHARACTERS. & KADISH. & FI BRID. \\
\hline $\begin{array}{c}\text { Cortex of stem at largest } \\
\text { part. }\end{array}$ & $\begin{array}{l}\text { Rather thick, compara- } \\
\text { tiv'ly, notcle'rly defin'd }\end{array}$ & $\begin{array}{l}\text { Thick, not clearly de- } \\
\text { fined. }\end{array}$ \\
\hline Wood of stem at largest part, & Dense ring, & Rather dense ring. \\
\hline Pith of stem at largest part, & $\begin{array}{l}\text { Spongy, dry, and } \\
\text { small amount, }\end{array}$ & $\begin{array}{l}\text { Succulent, and large } \\
\text { amount. }\end{array}$ \\
\hline Length of epidermal cells, & $46.5 \mu$, & $25 \mu$ \\
\hline Phloem of stem at largest part, & Well developed, & Well developed. \\
\hline Thickness of cortex of root, & $3650 \mu$, & $6000 \mu$. \\
\hline Xylem of root, & Rather scanty, & Rather abundant. \\
\hline Pith of root, & Abundant, & Scanty. \\
\hline Length of corticells of root, & $150 \mu$ & $60 \mu$. \\
\hline Bast fibers or root, & Absent, & Rather numerous. \\
\hline Rows of cells in med. ray of root, & 8, & 6. \\
\hline $\begin{array}{l}\text { Length of cells in med. ray } \\
\text { of root, }\end{array}$ & $45 \mu$ & $50 \mu$. \\
\hline $\begin{array}{l}\text { Thickness of wall of root } \\
\text { tracheids, }\end{array}$ & $1 \mu$ & $2 \mu$. \\
\hline $\begin{array}{l}\text { Composition of wall of root } \\
\text { tracheids, }\end{array}$ & Slightly lignified, & Somewhat lignified. \\
\hline Diameter of leaf, mid-rib, & $5500 \mu$, & $5000 \mu$. \\
\hline $\begin{array}{l}\text { Collenchyma cells around per- } \\
\text { iphery of mid-rib of leaf, }\end{array}$ & One layer, & One layer. \\
\hline $\begin{array}{l}\text { Diam. of ground tissue cells } \\
\text { of mid-rib, }\end{array}$ & $150 \mu$ & $135 \mu$ \\
\hline $\begin{array}{l}\text { Diam. of xylem vessels of } \\
\text { mid-rib, }\end{array}$ & $33 \mu$ & $35 \mu$. \\
\hline Thickness of leaf, lamina, & $330 \mu$, & $360 \mu$. \\
\hline Thickness of epidermal cells, & $15 \mu$ & $22 \mu$ \\
\hline Length of leaf palisade cells, & $45 \mu$ & $40 \mu$ \\
\hline Layers of leaf palisade cells, & $2-3$ & $3-4$ \\
\hline $\begin{array}{l}\text { Average number of stomates } \\
\text { in field of microscope, }\end{array}$ & 35, & 34. \\
\hline $\begin{array}{l}\text { Radial walls of lower epider- } \\
\text { mal cells of leaf, }\end{array}$ & Sinuous, & Nearly straight. \\
\hline $\begin{array}{l}\text { Length of lower epidermal } \\
\text { cells of leaf, }\end{array}$ & $75 \mu$ & $70 \mu$ \\
\hline
\end{tabular}


Radish, Kohlrabi, and Hybrid.

HISTOLOGICAL CHARACTERS TABULATED.

\begin{tabular}{|c|c|c|}
\hline KOHLRABI. & \% RADISH. & /\% KOHLRABI. \\
\hline Thin an 1 wall defined, & 80.0 & 20.0 \\
\hline Nearly absent, & 70.0 & 30.0 \\
\hline $\begin{array}{c}\text { Succulent and very large } \\
\text { amount, }\end{array}$ & 10.0 & 90.0 \\
\hline $30 \mu$ & $18 . x_{1}$ & 81.2 \\
\hline Rudimentary. & 90.0 & 10.0 \\
\hline $1800 \mu$ & 64.2 & 35.8 \\
\hline Abundant and dense, & 30.0 & 70.0 \\
\hline Absent, & 40.0 & 60.0 \\
\hline $50 \mu$ & 10.0 & 90.0 \\
\hline Numerous, & 40.0 & 60.0 \\
\hline $3-4$ & 5.5 .1 & 44.4 \\
\hline $28 \mu$ & $-\times 1 \overline{5}$ & $1 \pi .5$. \\
\hline $2.5 \mu$ & 33.3 & 66.7 \\
\hline Strongly lignified, & $40.1)$ & 60.0 \\
\hline $4000 \mu$ & 66.7 & 33.3. \\
\hline Two or more layers, & 100.0 & 0.0 \\
\hline $75 \mu$ & 80.0 & 20.0 \\
\hline $45 \mu$ & Si. 4 & 16.6 \\
\hline $300 \mu$ & 66.7 & 33.3 \\
\hline $23 \mu$ & 12.5 & 87.5 \\
\hline $33 \mu$ & $5 \times .4$ & 41.6 \\
\hline $3-4$ & 0.0 & 100.0 \\
\hline 24 & 91.0 & 9.0 \\
\hline Nearly straight, & 0.0 & 100.0 \\
\hline $45 \mu$ & $\times 3.4$ & 16.6 \\
\hline & 1304.5 & 1084.5 \\
\hline & 54.7 & 45.2. \\
\hline
\end{tabular}




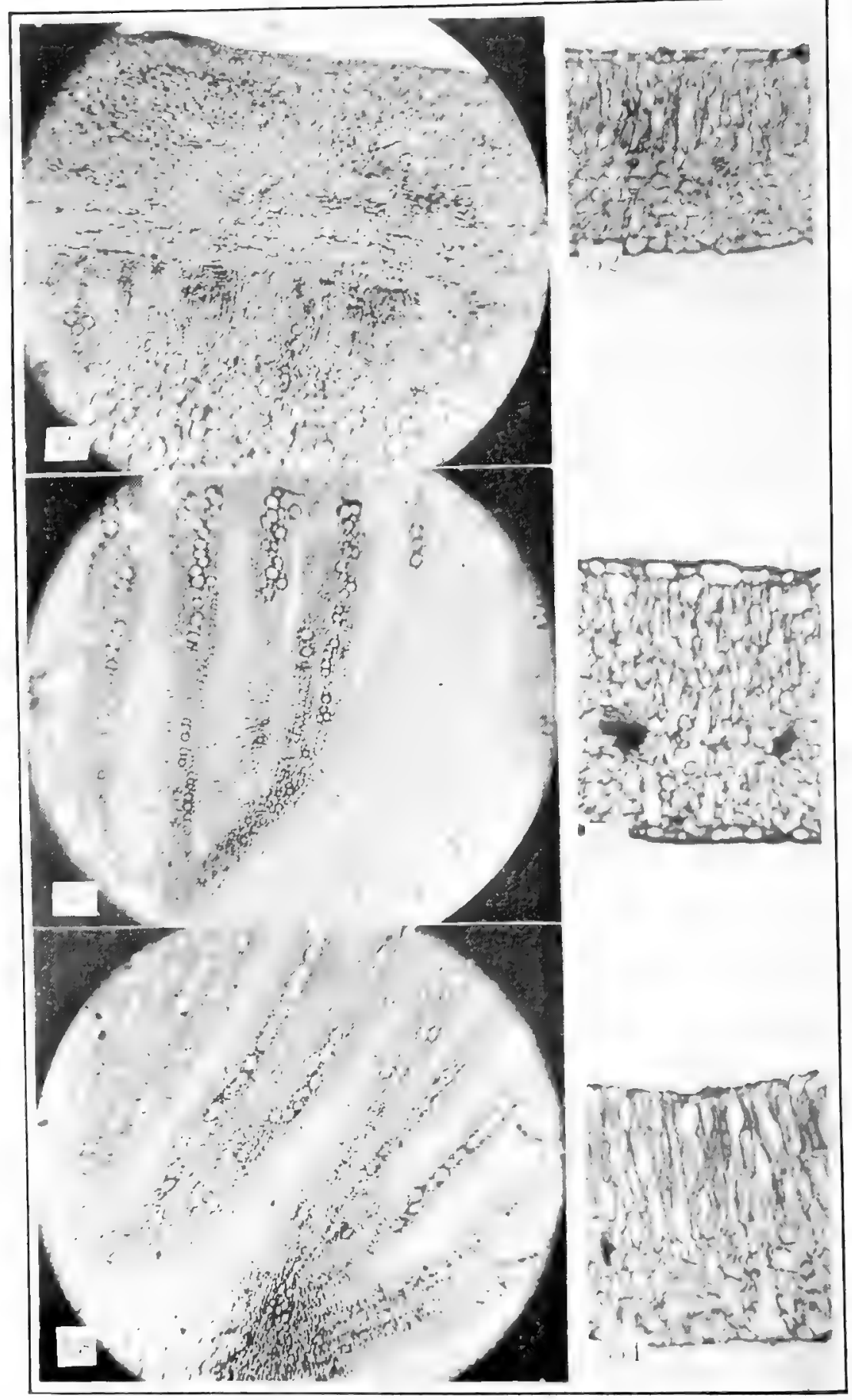


From the foregoing discussion and tables it is to be seen that the external characters of the Radish $\mathrm{x}$ Kohlrabi hybrid are $62.2 \%$ like the Radish parent and $37.8^{\prime \prime}$ " like the Kohlrabi parent. The microscopical characters show $54.7^{\circ} \%$ Radish characters and $45.3 \%$ Kohlrabi. The relationship here between external and microscopical characters is not so close as in the other hybrids discussed, still the difference is not very great, being less than $8 \%$, and the parent dominant in one set of characters is dominant in the other also. The pistillate parent had complete dominance over four of the external characters and one of the microscopical; the staminate parent had pure dominance over one external character and two internal. Of the sixteen external characters here considered, five show complete dominance; three of the twentyfive microscopical characters show dominance. Here as in the case of the other hybrids discussed, the great majority of tha characters are intermediate, yet the percentage is not so high.

\section{Other Hybrids.}

In addition to the hybrids already mentioned, the structure of certain others was studied briefly. Among these hybrids were Salix cordata $\times$ S. candida, Citrus trifoliata $\times$ C. aurantium, var. dulcis, Marshall strawberry x Crescent strawberry, Calceolaria hybrida x C. integrifolia, and Wild Goose Plum x Troth's Early Peach.

Salix Hybrids. Structure of leaves, twigs and fruit of the Salix hybrid was studied. The most interesting characters noted were as follows: Salix cordata has six rows of bast fibers, $\mathrm{S}$. candida three and the hybrid three. Differences were noted in the form and size of certain cells of the embryo of the three plants, but since the plants were open fertilized the parentage of the embryos is not ccrtain.

Citrus Hybrids. The structure of the fruit of several Citrus hybrids was studied. These hybrids were the result of duplicate and reciprocal crosses between Citrus trifoliata and C. aurantium, var. dulcis, and were produced by Dr. H. J. Webber of the U. S. Department of Agriculture. (For full description of the parents, see Cyclopedia of Horticulture, Vol. I, by L. H. Bailey, and for description of the hybrids see Year-book of Department of Agriculture for 1904, 1905 and 1906.)

The peel of these fruits proved most satisfactory for the comparison of structure. In Citrus aurantium, var. dulcis, the peel is $5-1 \mathrm{~mm}$. thick on ripe fruit; in C. trifoliata, it is $2-4 \mathrm{~mm}$. thick; on the hybrids it varies considerably, being $3-5 \mathrm{~mm}$. thick in Rusk citrange, $4-6 \mathrm{~mm}$. in Willit's citrange, $4-6 \mathrm{~mm}$. in Citrange $767,3-6 \mathrm{~mm}$. in Citrange 775 , 4.5-6.5 $\mathrm{mm}$. in Citrange 783, 4-5 $\mathrm{mm}$. in Morton citrange, and 3.5-5 $\mathrm{mm}$. in Citrange 761. The hybrids are intermediate in this character, but nearer the female parent in most cases. Citrus aurantium, the sweet orange, was the female parent in all crosses, except in the Rusk citrange.

The epidermal cells of the peel were $27 \mu$ long in the Citrus trifoliata, and $15 \mu$ long in $\mathrm{C}$. aurantium. The hybrids were all intermediate but nearer the sweet orange parent. No difference was to be noted in the reciprocal crosses in regard to this character. The outer wall of the 
epidermal cells was $9 \mu$ thick in C. trifoliata, $1-2 \mu$ thick in C. aurantium, while the hybrids are all intermediate; no difference in reciprocal crosses.

The number, size and shape of the oil glands in the peel differed considerably in the two parent species, while the hybrids in nearly every case possessed an intermediate amount of the character. The characters of the $\mathrm{C}$. aurantium parent were dominant in the hybrid in the great majority of cases whether used as pistillate or staminate parent. In all of the characters studied, there seems to be no definite or uniform influence of either parent over any special part.

Fragaria Hybrid. No part, except leaves of the Fragaria hybrid' was examined. The form and size of the leaves of the two parents and hybrid differed somewhat, but they all seemed to be very similar structurally.

\section{Genera?.}

The limits of characters belonging to species of plants are not definite, or sharply defined. If we examine their structural basis, we find that they depend upon the number, size or nature of the cells in certain parts of the plant, or in the plant as a whole. Since the number and nature of the cells varies somewhat in different individuals of the species, the characters formed by them must vary and are consequently only relative considering the species as a whole.

A hybrid character that appears to show pure dominance may upon close examination be found to be intermediate if its structural basis be examiner. The xylem of the root of the Radish $\mathrm{x}$ Kohlrabi hybrid illustrates this; the central part of this root when examined macroscopically, appears to be dense wood, as dense as the wood of the central part of the root of the Kohlrabi parent, but if this xylem is examined microscopically it is found to have a considerably larger per cent. of thin-walled unlignified cells, thus presenting a structure intermediate between the two parents. There may be a dominance in the size of the whole structure or part, or even in the size of the cells, yet the hybrid tissue may lack in substance or may not have the same chemical composition as the corresponding tissue of the apparently dominant parent. In case of color, too, where the color is due to a dye such as anthocyanin, the presence of half the amount of the coloring matter in the hybrid might produce a color apparently as dense as in the one parent that appears to be dominant in respect to this character. The character may be diluted and the dilution not apparent. Considering all, we are inclined to think that pure dominance is not so frequent as it is commonly thought to be.

In the plants studied it does not scem that either parent exerted a uniform influence over the whole hybrid or upon any of its parts. In the Nicotiana Tabacum $x$ N. sylvestris hybrid, the greater per cent of its characters, both morphological and histological, were inherited from $\mathrm{N}$. Tabacum, the pistillate parent. The N. Tabacum x N. alata hybrid shows that the larger part of its inheritance, both in histological and morphological characters, is from $\mathrm{N}$. alata, the staminate parent. Over some characters such as shape and size of leaves, the pistillate parent is 
dominant in one cross and the staminate in the other. In the Citrus hybrids one parent plant was dominant in regard to certain characters, as for instance, the size of epidermal cells of fruit, whether used as pistillate or staminate parent. C. aurantium was always dominant in respect to this character. The influence of the staminate parent over the epidermal structures of the hybrid, such as Gauchery (1902) pointed out in a hybrid between ('istus salvifolius and Helianthemum halimifolium, does not show in the hybrids studied nor was there a uniform influence of either parent as claimed by Denny (1872) for Pelargonium hybrids.

In the great majority of cases the cells of the hybrids studied were intermediate between the corresponding cells of the parents. This indicates that there must have been a complete blending of parental elements. But exceptional cases showed that a blending had not taken place, or if it had, it must have been followed by a segregation of characters. For instance, certain epidermal cells of the calyx of the Calceolaria hybrid formed glandular hairs, and other epidermal cells simple hairs, one parent having glandular hairs on its calyx and the other simple only.

A hybrid between Wild Goose Plum and Troth's Early. Peach showed that segregation had advanced a step farther; whole patches of epidermal cells of the twigs were exactly like the epidermal cells of either parent. Hildebrand (1889) reports an interesting case of segregation taking place within a single cell. In a hybrid between Oxalis 1atifolia and $\mathrm{O}$. tetraphylla he found the characteristic hairs of the two parent species might both arise from a single epidermal cell of the hybrid.

The fact that the starch grains of the Nicotiana Tabacum x $N$. sylvestris hybrid were very much larger than the grains of either parent indicates that there is more than a mere passing over of the leucoplastids from the parents. The plastids from the two parents cither fused, or were subjected to some sort of a stimulus resulting from the mixing of the parental elements which caused the production of the large grains. MacFarlane (1891) was of the opinion that many of the starch grains of Hedychium hybrids were intermediate between those of their parents. I am inclined to think that that is true of the grains of Nicotiana hybrids too, especially as regards shape of grains, but the variation in shape in the grains of the hybrid is so great that it is difficult to be certain.

All of the species hybrids studied were sterile when self pollinated. In all cases examined, the pollen began to break down while in the resting state. The ovules looked perfectly normal, but they were not studied in detail. In the Nicotiana hybrids they failed to form seed even when pollen from the parent specics was used. In the Radish $\mathrm{x}$ Kohlrabi hybrid, the ovules enlarged when the flowers were pollinated with Kohlrabi pollen, but no perfect seed was formed.

The Plum x Peach hybrid produced numerous flower buds but they failed to open. From the tip of some, the stigmas and styles of several rudimentary pistils projected. These pistils contained ovules in the ovary of each. No stamens were developed. (For an account of the production and description of this hybrid see Report of Cornell ExpStation, for 1892.) 
That hybrids are commonly sterile is a matter of frequent observation, but the exact cause of this sterility is still largely unknown. It is very probable, as De Vries suggests, that there is a lack of harmony within a part of the cells due to the failure of certain characters to find their mates,-they remain unpaired, disturbing elements in the society of the cell.

\section{Summary.}

1. The majority of the characters of the hybrid plants studied, were intermediate between the corresponding characters of the parents; 100 of the 121 characters tabulated were intermediate.

2. Nicotiana Tabacum, when used as a pistillate parent in a cross with Nicotiana sylvestris, influenced the external or morphological characters of the hybrid to the extent of $64.6 \%$, and the histological characters $61.9 \%$. The staminate parent, N. sylvestris, had influence to the extent of $35.4 \%$ and $38.1 \%$ respectively.

3. Nicotiana Tabacum, when used as a pistillate parent in a cross with Nicotiana alata had influence over the external characters of the hybrid to the extent of $36.5 \%$, and over the histological characters, $37.2 \%$. The staminate parent, N. alata, had influence to the extent of $63.5 \%$ and $62.8 \%$ respectively.

4. Raphanus sativus, when used as a pistillate parent in a cross with Brassica oleracea var. caulo-rapa, had influence over the external characters of the hybrid to the extent of $62.2 \%$, and the histological of $54.7 \%$. B. oleracea, var. caulo-rapa had influence to the extent of $37.8 \%$ and $45.3 \%$ respectively.

5. There is a close relation between external and histological characters. In every hybrid studied, the parent having the higher per cent. of dominance in one set of characters was also dominant in the other set by about the same per cent., the difference being, as can be seen from the figures given above, $2.7 \%, .7 \%$, and $7.5 \%$.

6. Neither parent, in the crosses studied, exercised a uniform influence over any particular characters of the hybrid or over the sum total of characters.

This work was done in the botanical laboratory of Cornell University. I wish to thank Prof. W. W. Rowlee, for advice and criticism during the prosress of the work, ard I also wish to express my indebtedness to Dr. H. J. Webber for many helpful suggestions and assistance in various ways. 


\section{BIBLIOGRAPHY.}

1901. BRIQUET;

Anatomie comparé de la feuille chez le Pistachio Lentiscus, Terebinthus et Saportae.

Bull. Herb. Boissier, p. 1301.

1909. Canion, W. A.;

Studies in Heredity as illustrated by the trichomes of species and hybrids of Juglans, OEnothera, Papaver and Solanum.

Pub. 117, Carnegie Institution, Wáshington, D. C.

1905. Dagílllon, Arg.;

Remarkes anatomiques sur Linaria $\mathrm{x}$ striato-valgaris.

Rev. Gén. Bot. Paris XVII, p. 508-518.

Botan. Jahrb. Vol. 33-2.

1868. DARWIN, ChaRles;

Variation of Animals and Plants under Domestication. Vol. II, p. $4 x$.

1872. DENNY, J.;

The Relative Influence of Parentage in Cross-Breeding. Gar. II, 15.

1897. FARMER, J. B.;

On the Structure of a Hybrid Fern.

Ann. Bot., Dec. 1897, p. 533.

1902. Gauchery, P.;

Notes anatomiques sur l'hybridité.

(Assoc. franc., ajaccio, 1902.)

Vergl. Bot. Centralbl. Bd. 90, p. 467.

1911. Groth, B. H. A.;

The $F_{1}$ Heredity of Size, Shape, and Number in Tomato Leaves, Part I, Seedlings.

Bul.1 No. 238, N. J. Experiment Station.

1911.

The F1 Heredity of Size, Shape and Number in Tomato Leaves. Part II, Mature Plants.

Bull. No. 239, N. J. Experiment Station.

1912.

The $F_{1}$ Heredity of Size, Shape and Number in Tomato Fruits. Bull. No. 242, N. J. Experiment Station.

1833. HENSLOW, J. S.;

On the Examination of a Hybrid Digitalis.

Comb. Phil., Trans. Vol. IV.

1889. HildeBrand, F.;

Ueber einige Pflanzenbastardierungen.

Jen. Zeitschr. Bd. 23.

1890. MacFarlane, J. M.;

The Microscopic Structure of Hybrids.

Gar. Chron. 3 ser., VII, p. 543.

1891. MacFarlane, J. M.;

A comparison of the Minute Structure of Plant Hybrids with that of their Parents and its Bearing on Biological Problems.

Trans. Roy. Soc., Edinburgh. X X XVII, p. 1, No. 11. 
1900. MacFarlane, J. M.;

Observations on Some Hybrids between Drosera filiformis and D. intermedia.

Jour. of the Royal Hort. Soc, Vol. 24.

1897. Parmentier, P.;

Recherches anatomiques et taxinomiques sur les rosiers.

Ann. Sc. Nat. Bot. VIII, série. t VI. Bot. Jahresb. Vol. $26-2$, p. 223.

1900. Paulesco, P.;

Recherches sur la structure anatomique des hybrides.

Thèse Genève.

Bot. Jahresb. Vol. 29-2, p. 408.

1905. Penhallow, D. P.;

The anatomical changes in the Structure of the Vascular Cylinder incident of the Hybridization of Catalpa.

Amer. Naturalist, XXXIX, p. 113.

1896. Smith, Elmer D.;

Prepotency of the Male Parent.

Gar. Chron. XIX, 791.

1888. WeTtSTEIN;

Sistz. der Kaiser. Akad. der Wissen.

Vol. XCVI.

1900. Wilson, J. H.;

The Structure of some new Hybrids.

J. of Horticultural Soc. Dd. X XIV.

1895. WUNDERLICH, JOH;

Beiträge zur anatomischen characteristik der Circium Bastarde. (Diss. Erlangen) 41, p. $8^{\circ}$ u. 2 Taf. Altenberg. Ref. Bot. C. LXV. p. 352 .

1895. ZsCHOKKE, A.;

Ueber die anatomische Structur des Bastardes Carex ampullacea $\mathrm{x}$ vesicaria.

Vgl. Ber. Schweiz. Bot. Ges. 


\section{EXPLANATION OF FIGURES.}

Fig. 1. Nicutiana Tabacum.

Fig. 2. Nicotiana sylvestris.

Fig. 3. X. Tabacum $x$ X. sylvestris. (Photographs of the three plants taken soon after they began to blosis,m.)

Fig. 4. Flowers and flower parts of; (a.) Nicotiana alata: (b.) X. Tabacum: (c.) Hybrid.

Fig. 5. Flowers and flower parts of; (a.) N. Tabacum: (b.) N.. sylvestris: (c.) Hybrid.

Fig. 6. Leaves of; (a.) N. Tabacum: (b.) N. sylvestris: (c.) Hytrirl.

Fig. 7 . Nicotiana alata at maturity.

Fig. $\$$. Tabacum $\times$. . alata at maturity.

Fig. 9. Cortex, wood and pith of $X$. Tabacum.

Fig. 10. Cortex, wood and pith of $X$. sylvestris.

Fig. 11. Cortex and portion of wood and pith of N. Tabacum $x$ V. sylvestris.

Fig. 12. Cortex, wood, and pith of N. alata.

Fig. 13. Cortex, wood, and pith of N. Tabacum $x$ N. alata.

Fig. 14. Cross section of anther of $X$. Tabacum $x \times$. sylvestris.

Fig. 15. Cross section of $N$. sylvestris anther.

Fig. 16. Cross section $N$. alata corolla.

Fig. 17. Cross section $N$. alata calyx.

Fig. 14. Cross section N. Tabacum $x$ N. alata corolla.

Fig. 19. Cross section $\lambda$. Tabacum $x$. alata calyx.

Fig. 20. Cross section X. Tabacum corolla.

Fig. 21. Cross section $X$. Tabacum calyx.

Fig. 22. Cross section $X$. alata leaf lamina.

Fig. 23. Cross section $\mathcal{X}$. Tabacum $x \mathcal{X}$. alata leaf lamina.

Fig. 24. Cross section $N$. Tabacum leaf lamina.

Fig. 25. Cross section $N$. Tabacum $x \mathrm{~N}$. sylvestris lenf lamina.

Fig. 26. Cross section $N$. sylvestris leaf lamina.

Fig. 27. $\therefore$. Tabacum starch grains.

Fig. 28. N. Tabacum $\mathrm{x} \times$. sylvestris starch grains.

Fig. 29. $\perp$. Sylvestris starch grains.

Fig. 30. Cross section N. Tabacum anther.

Fig. 31. Cross section $N$. Tabacum $x ~ N$. alata anther.

Fig. 32. Cross section N. alata anther.

Fig. 33. Radish parent soon after beginning to blossom.

Fig. 34. Kohlrabi parent soon after beginning to blossom.

Fig. 35. Hybrid between Radish and Kohlrabi soon after beginning to blossom.

Fig. 36. Hybrid between Radish and Kohlrabi at maturity, showing roots and lower part of stem.

Fig. 37. a. Cross section of Kohlrabi root.

b. Cross section of Kohlrabi stem through thickened portion.

Fig. 38. a. Cross section of Radish root.

$b$. Cross section of Radish stem corresponding to $37 b$.

Fig. 39. $u$. Cross section of Radish $\times$ Kohlrabi root.

b. Cross section of Radish $\mathrm{x}$ Kohlrabi stem corresponding to $37 b$. 
Fig. 40. a. Radish leaves.

b. Kohirabi leaves.

c. Hybrid leaves.

Fig. 41. Flower and parts of;

a. Radish.

b. Kohlrabi.

c. Hybrid.

Fig. 42. Lower epidermal cells of Kohlrabi leaf.

Fig. 43. Lower epidermal cells of Hybrid leaf.

Fig. 44. Lower epidermal cells of Radish leaf.

Fig. 45. Cross section of Radish root.

Fig. 46. Cross section of Hybrid root.

Fig. 47. Cross section of Kohlrabi root.

Fig. 48. Cross section of wood in lower portion of Radish stem.

Fig. 49. Cross section of tissue in Kohlrabi stem: corresponding to section for Fig. 48.

Fig. 50. Cross section of tissue in Hybrid stem: corresponding to section for Fig. 48 .

Fig. 51. Cross section of Radish leaf lamina.

Fig. 52. Cross section of Kohlrabi leaf lamina.

Fig. 53. Cross section of Hybrid leaf lamina. 







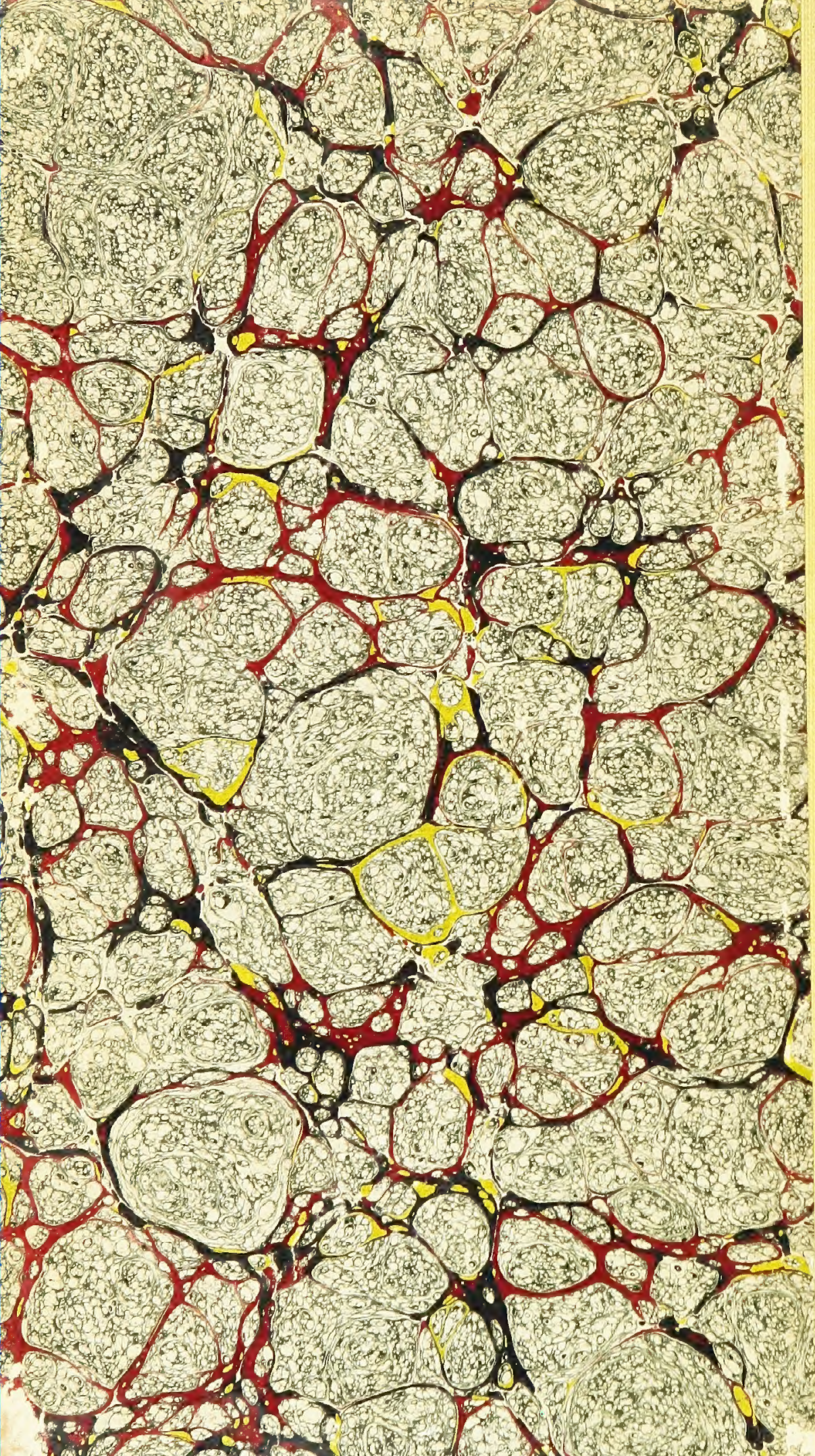

